\title{
Every tenth child: \\ Heterogeneity in characteristics and life-course patterns among children in contact with child welfare services*
}

\author{
Nicolai T. Borgen ${ }^{1}$, Ivar Frønes ${ }^{2,3}$, and Oddbjørn Raaum ${ }^{4}$ \\ ${ }^{1}$ Department of Special Needs Education, University of Oslo, Norway \\ 2 Norwegian Center for Child Behavioral Development, Norway \\ ${ }^{3}$ Department of Sociology and Human Geography, University of Oslo, Norway \\ ${ }^{4}$ The Ragnar Frisch Centre for Economic Research, Norway
}

February 2022

\begin{abstract}
Every tenth Norwegian child has been in contact with the child welfare services (CWS) before age 18. This paper describes the variation in background characteristics of CWS children with different types of services and their life-course trajectories from ages 10 to 25 , compared to other children. We use high-quality population-wide Norwegian register data, covering about 860000 children from birth cohorts 1987-2001, of which roughly 85000 have received a CWS initiative. CWS children typically have lower socioeconomic backgrounds than other children. In terms of individual outcomes, they are more likely to have a criminal charge, be prescribed drugs for mental health and ADHD, fail in the educational system, and experience labor market marginalization. However, the heterogeneity among CWS children receiving different initiatives is more pronounced than differences between those in contact and those not. Adolescents with multisystemic therapy (MST) have the most unfavorable life-course patterns, in line with children in childcare institutions. Still, MST youth enter CWS late and have an advantaged family background compared to other CWS children, suggesting that individual-level risk factors are particularly important for sorting into MST.
\end{abstract}

Keywords: Child welfare services, crime, mental health problems, ADHD, education, labor market

\footnotetext{
* Earlier version of this paper were presented at the Norwegian Center for Child Behavioral Development. This work is supported by funding from the Norwegian Research Council (\#288813 and \#238050). The register data is made available for research by Statistics Norway. Individual drug prescriptions are from the Norwegian Prescription Database, provided by the Norwegian Institute for Public Health.
} 


\section{Introduction}

The last decades have brought a series of studies on the background characteristics of children in public care (Bebbington and Miles 1989; Berger 2004; Franzén, Vinnerljung, and Hjern 2007; Lindsey 1991, 1992; Pelton 2015). A parallel literature portrays the developmental outcomes for children in contact with child welfare systems (Brännström et al. 2017; Jozefiak et al. 2016; Vinnerljung, Hjern, and Lindblad 2006; Vinnerljung, Öman, and Gunnarson 2005). However, although there are notable exceptions (Vinnerljung, Hjern, and Lindblad 2006; Vinnerljung, Öman, and Gunnarson 2005), the child welfare service (CWS) literature is dominated by small-scale studies. Furthermore, most studies focus on specific child welfare initiatives, such as out-of-home care (e.g., Brännström et al. 2017; Doyle Jr 2007).

This study brief contributes to this literature by describing the characteristics and life-course trajectories of CWS children in Norway using population-wide register data. Like in Sweden (Vinnerljung, Hjern, and Lindblad 2006), CWS is not a marginal phenomenon in Norway as nearly every tenth child (or their parents) receives CWS initiative within the age of 18 . These CWS children constitute a heterogeneous group regarding parental and child characteristics. Variation applies to the content of the services and initiatives as well. Fullpopulation register data allow us to compare children receiving different services, including foster homes, childcare institutions, multisystemic therapy (MST), and in-home services. Such comparisons provide valuable information about specific characteristics of children receiving different types of care. Most CWS initiatives are motivated by parental neglect and socioeconomic deprivation. Still, services to tackle children's behavioral problems are also common, especially among CWS entrants in their teens.

The richness, scale, and longitudinal nature of register data allow us to give detailed descriptions of the backgrounds and early life-course trajectories of CWS children. By type of service, we describe children's background characteristics, measured by parental criminal records as well as standard measures like parental education, earnings, and welfare benefits. Additionally, the longitudinal nature of the register data allows us to follow children from adolescence to early adulthood. We start by examining early school performance, including grades and school behavior. Then, we study life-course trajectories up to age 25 in children's criminal charges, prescription drugs, completion of upper 
secondary education, probability of receiving welfare benefits, and the likelihood of being outside of both the labor market and education.

This article's overall aim is to describe the characteristics and life-course trajectories of CWS children rather than identifying the causal effects of specific initiatives. Partly, differences in life-course trajectories could reflect the effects of child welfare services. However, differences could also reflect causes for child welfare services contact; especially early, adverse outcomes such as poor school behavior or criminal charges could result in a child being contacted by child welfare services. In addition, there are likely to be unobserved individual and family environment factors that trigger CWS services and directly affect outcomes ("confounding"). Nevertheless, understanding the sorting and trajectories of CWS children may be valuable for studies attempting to identify causal effects of initiatives (e.g., Bald et al. 2019; Doyle Jr 2007, 2008).

\section{Materials and methods}

\subsection{Study context}

Although child protection systems typically are based on a common ground of public responsibility for children at risk, and there are indications that the systems are converging, there is still a great deal of variability between countries (Berrick et al. 2017; Gilbert 2012). In Norway, the CWS is regulated by the law to protect and assist children and youth who live in conditions detrimental to their health and development. Children and parents in need of assistance are met by the local CWS, which has several possible support and treatment initiatives, varying with the severity and origin of problems as well as the age of the child (Langford, Skivenes, and Søvig 2019).

\subsection{Register data}

We use population-wide Norwegian register data covering all children born in Norway between 1987 and 2001 (approx. 860,000). Immigrant children arriving in Norway after birth are excluded since we study children's life-course trajectories in this paper, while children of immigrants born in Norway are included. We combine data from various registers, including records of child welfare services, school career, criminal charges, 
prescription drugs, and family background. The register data enable us to follow children as they move through the life courses, and the data contains reliable information without attrition bias. ${ }^{1}$

\subsection{Measures}

\subsubsection{Child welfare service measures}

Our child welfare services data include CWS records from 1994 to 2016 . The children in contact with CWS often receive several different interventions throughout their childhood; we approach this heterogeneity by classifying CWS children according to the most extensive intervention. Some individual CWS experiences lean to an uncontroversial classification, others not. An easy-to-classify example is a girl who received in-home initiatives during early childhood and moved to a child care institution in her teens. This girl is classified as a child care institution child, as in-home initiatives are naturally considered lighter than foster homes and institutional care. It is less straightforward to rank out-of-home care such as enhanced foster homes relative to in-home measures rooted in a child's behavioral problems such as MST. The MST program, directed at parents of teens with severe behavioral issues, is frequently offered as an alternative to institutions or forms of incarceration. We believe that MST children's characteristics and life course trajectories are of specific interest and have chosen to rank MST after child care institutions.

Building on this reasoning, we distinguish between seven child welfare measures, where CWS children have one unique value (from the most extensive to the least extensive): (1) child care institutions (short and long stays), (2) MST, (3) enhanced foster homes, (4) foster homes, (5) kinship foster homes, (6) in-home initiatives. In-home measures include counseling, advisory services, financial assistance, support groups, and more, excluding MST. Note that many children have received multiple initiatives throughout childhood. For

\footnotetext{
${ }^{1}$ Since the data window differs across administrative registers, available information varies between birth cohorts. For example, we can only observe CWS initiatives for children born in 1987 from age seven and onwards. Thus, some children with early contact are recorded as receiving no initiative for this birth cohort. We have investigated life-course patterns of children where we can observe nearly complete child welfare service histories (birth cohorts 1992-1995) in Supplementary Online Appendix B. The results for these birth cohorts are very similar to the main results. Therefore, we have chosen to keep all birth cohorts to follow children longer. An overview of variable coverage in different birth cohorts can be found in the Supplementary Appendix Table A3, while summary statistics can be found in Table A1.
} 
example, $26 \%$ of children who received MST have also stayed in childcare institutions (Table A2).

The majority of CWS children only receive in-home measures $168 \%$ of the CWS children, or 6.7 percent of all children) during childhood and adolescence. Next, $1.5 \%$ are in various foster homes, and $1 \%$ stay at a childcare institution at least once during childhood. Finally, $0.6 \%$ receive MST. In-home measures are used over the whole childhood period, while MST and out-of-home measures, especially placement in childcare institutions, peak in early adolescence (Figure 1). The high entry age of many MST children reflects that early adolescence is a phase where behavior problems grow salient, indicating a group of children that enter child welfare services late because of increasing behavioral problems (and not because of parental neglect).

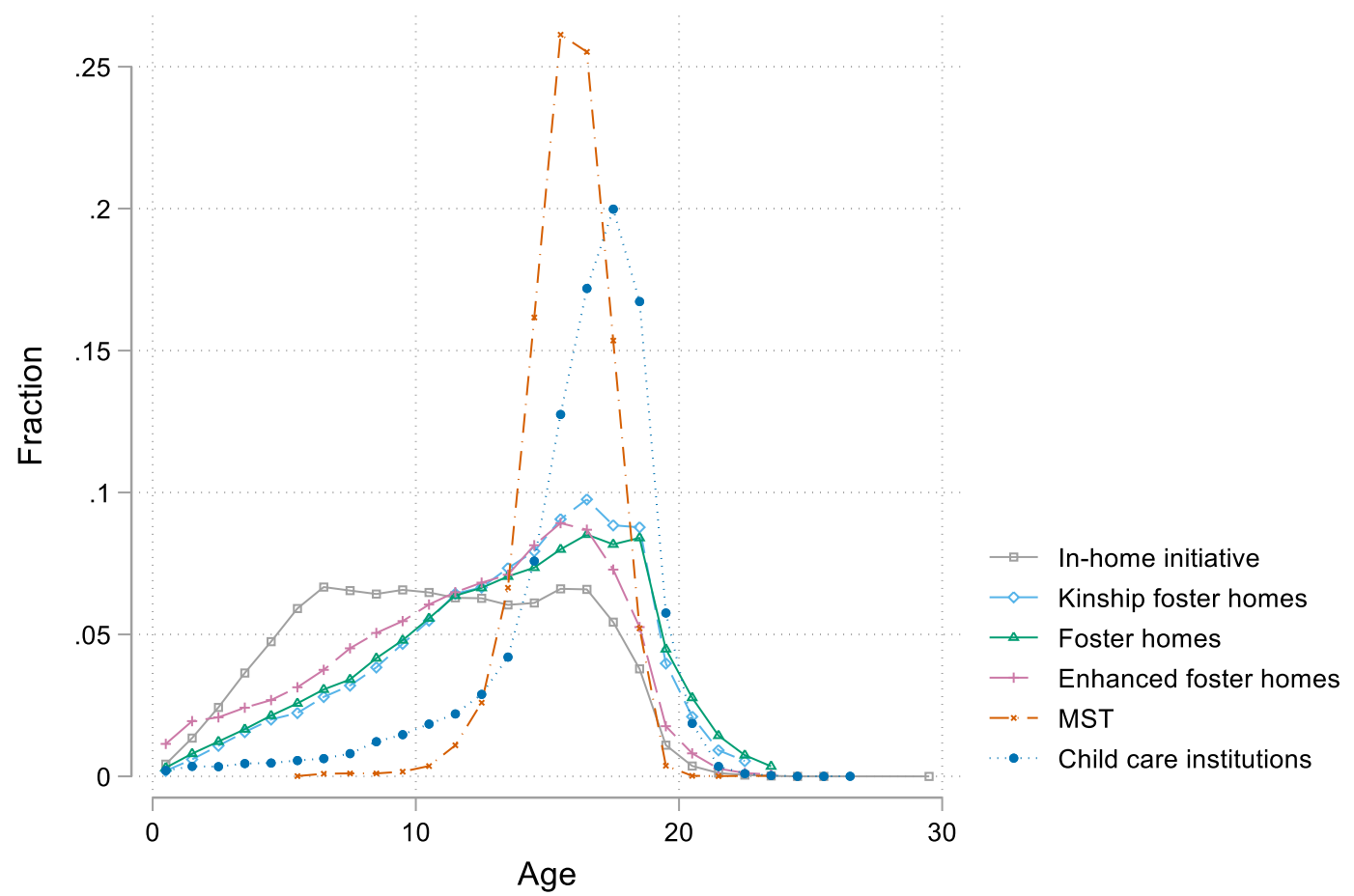

Figure 1: Distribution of child welfare measures by age for CWS children.

Note: Sample consists of 140,159 individuals in contact with the CWS with 566,449 person-year observations. The age composition is similar for boys and girls; see Appendix Figure A1. The age of first contact with CWS for children with different services can be found in Figure A7.

The child welfare services register includes information on the reasons for each CWS initiative. The classification is done by the local CWS caseworker, and we use two main 
categories based on the record for the child's most extensive initiative: the child's behavior problems and parental neglect. The caseworker sometimes records both as motivation, and in those cases, we classify the reason as child behavioral problems.

\subsubsection{Background measures}

The first aim of the analysis is to examine the characteristics of the children in contact with the child welfare services and various types of initiatives within the child welfare services. First, we distinguish between the caseworker's record of parental neglect (1=yes) and child behavioral problems (1=yes), as well as the child's gender.

Our family-level measures of parental socioeconomic background include parents' years of education equal to the average of mother's and father's years of education. Parents' earnings is defined as the earnings rank of mother's and father's average earnings between 11 and 15 years of age. The earnings are ranked in percentile rank by birth cohort, where children with parents' with the lowest earnings receive 0 and children with parents with highest earnings receive 1 . Parents' criminal charges measure whether either the father or mother has been charged with at least one felony when the child is between 10 and 12 years of age. Parents' social welfare benefits is a dummy variable for whether the father or the mother has received welfare benefits at least once when the child is between 10 and 12 years of age. Finally, immigrant background is defined as children born to two non-Norwegian-born parents. All parental measures are based on biological parents, as defined by the official Population register.

\subsubsection{Life course outcomes}

Children's educational trajectories are measured using $10^{\text {th }}$-grade academic achievements, poor school behavior, and school absence, as well as the upper secondary completion between ages 18 and 25. Academic achievements are measured using the grade point average (GPA) on the school-leaving certificate from lower secondary education $\left(10^{\text {th }}\right.$ grade), and it is standardized to have a zero mean and a standard deviation of 1 . Poor school behavior is obtained from marks in orderliness and conduct in $10^{\text {th }}$ grade, which is included at the school-leaving certificate from lower secondary education and distinguishing between good, fair, and poor. The student's teachers grade the order and conduct, and the marks reflect behavior such as being late to class, not doing homework, being violent, and 
cheating on tests. School absence hours and absence days include all undocumented absences between $8^{\text {th }}$ and $10^{\text {th }}$ grade and are printed at the school-leaving certificate from lower secondary education. Absence hours are registered if a student misses some school hours, while whole days are registered as absence days. Each school year, up to 10 absence days can be excluded if students have documented reasons for absence, such as health.

Criminal charges measure whether children have been charged for a criminal act annually from age 10 to age 25 , and we distinguish between felony offenses and misdemeanors.

Welfare benefits indicate whether children have received welfare benefits (1=yes) annually from ages 18 to 25 . Not in education, employment, or training (NEET) is also measured annually from ages 18 to 25 . Individuals are considered NEET if they are not registered in education and their total annual pre-tax income from employment and selfemployment is less than 1 basic amount (b.a.) (1=yes). ${ }^{2}$

Finally, as health problem proxies, we use individual records from the Norwegian Prescription Database (NorPD), a national health register that tracks drugs dispensed by prescription since 2004. Drugs purchased without a prescription are not included, nor are drugs supplied to hospitals and nursing homes. NorPD classifies drugs according to the World Health Organization Anatomical Therapeutic Chemical (ATC) classification system. We focus on psycholeptic drugs (N05) and psychoanaleptic drugs (N06) within ATC group N (Nervous system), and measure annual prescriptions of different types of drugs from ages 10 to 24 . We distinguish between antidepressants, anxiolytics, hypnotics and sedatives, antipsychotics, and centrally acting sympathomimetics (i.e., ADHD drugs). ${ }^{3}$

\footnotetext{
${ }^{2}$ The b.a. is used in the Norwegian pension and social welfare system to assess whether individuals are eligible for various benefits, including welfare and unemployment benefits. 1 b.a. consituted 100853 NOK in 2020.

${ }^{3}$ The prescription drugs groups are based on levels 3 and 4 of the ATC classification system. Antidepressants are defined as prescriptions with ATC code N06A, which comprise preparations used to treat endogenous and exogenous depressions as well as anxiety. Anxiolytics (ATC N05B) comprise preparations used to treat neuroses and psychosomatic disorders associated with anxiety and tension, including certain benzodiazepines. Hypnotics and sedatives (ATC N05C) comprise preparations with mainly sedative or hypnotic actions, including z-hypnotics and melatonin receptor agonists. Antipsychotics (ATC N05A) includes drugs with antipsychotic actions. Finally, centrally acting sympathomimetics (ATC N06BA) are primarily used to treat ADHD. Not that there is no one-to-one relationship between a specific prescription drug and a diagnosis or problem (Skurtveit et al. 2018; Wong et al. 2016). For example, while selective serotonin reuptake inhibitors (SSRIs) are classified within the ATC classification system as antidepressants, they are also the preferred drug for treating pediatric anxiety disorders (Ask et al. 2019; Wesselhoeft et al. 2020).
} 
Note that some life-course outcomes are measured while children are potentially in public care, while others are measured after CWS contact. For example, MST children often enter CWS late, and school behavioral problems (i.e., $10^{\text {th }}$-grade school measures) may lead to the involvement of CWS. In contrast, upper secondary school completion is measured at ages 18 to 25 , practically after CWS for all children.

\subsection{Data analysis}

In our description of CWS children's characteristics and life course trajectories, we compare subgroups within CWS by type of service before age 18. For these subgroups, the average background characteristics and life-course outcomes are compared, and as a baseline, we also compare with children without CWS experience. We look at boys and girls combined in the main results since their patterns are similar. ${ }^{4}$

Additionally, we report adjusted differences in the life-course outcomes where parental characteristics and gender are controlled for in linear least squares regressions. Importantly, unobserved family and child characteristics likely influence both CWS initiative and child outcomes (Bald et al. 2019), which means that these analyses are not suitable to identify causal effects of CWS initiatives. However, a comparison of unadjusted and adjusted models is informative on the selection into different types of CWS.

\section{Results}

\subsection{Background characteristics of CWS children}

The first aim is to describe the background characteristics of children in contact with child welfare services (Table 1). As expected, parents of CWS children have fewer years of education, lower earnings, are more likely to receive welfare benefits, and are more likely to be charged for a felony than parents in general (columns 1-4 in panel A). For example, the proportion of parents receiving welfare benefits is 41 percentage points higher among CWS children than among other parents (column 4). Parents of CWS children are also more likely to be immigrants.

\footnotetext{
${ }^{4}$ Supplementary Figure A2, Figure A3, Figure A4, and Figure A5 show that although the average outcomes differ by gender (e.g., boys have higher levels of youth crime), the life-course patterns and differences between CWS initiatives are similar.
} 
Table 1: Background characteristics of CWS children compared to other children.

\begin{tabular}{|c|c|c|c|c|c|c|c|c|}
\hline & $\begin{array}{c}\text { (1) } \\
\text { Educ. }\end{array}$ & $\begin{array}{c}(2) \\
\text { Earnings }\end{array}$ & $\begin{array}{c}(3) \\
\text { Felony }\end{array}$ & $\begin{array}{c}(4) \\
\text { Welfare } \\
\text { benefits }\end{array}$ & $\begin{array}{c}5) \\
\text { Immigrants }\end{array}$ & $\begin{array}{l}(6) \\
\text { Girl }\end{array}$ & $\begin{array}{c}(7) \\
\text { Parental } \\
\text { Neglect }\end{array}$ & $\begin{array}{c}\text { (8) } \\
\text { Child } \\
\text { behavioral } \\
\text { problems }\end{array}$ \\
\hline \multicolumn{9}{|l|}{ Panel A } \\
\hline \multicolumn{9}{|l|}{ No initiative (ref) } \\
\hline CWS (1=yes) & $\begin{array}{c}-1.706^{* * *} \\
(0.009)\end{array}$ & $\begin{array}{c}-0.284^{* * *} \\
(0.001)\end{array}$ & $\begin{array}{c}0.130^{* * *} \\
(0.001)\end{array}$ & $\begin{array}{c}0.409^{* * *} \\
(0.001)\end{array}$ & $\begin{array}{c}0.038^{* * *} \\
(0.001)\end{array}$ & $\begin{array}{c}-0.025^{* * *} \\
(0.002)\end{array}$ & $\begin{array}{l}0.671^{* * *} \\
(0.001)\end{array}$ & $\begin{array}{l}0.299^{* * *} \\
(0.001)\end{array}$ \\
\hline \multicolumn{9}{|l|}{ Panel B } \\
\hline In-home initiative & $\begin{array}{c}-1.540^{* * *} \\
(0.010)\end{array}$ & $\begin{array}{c}-0.255^{* * *} \\
(0.001)\end{array}$ & $\begin{array}{l}0.096^{* * *} \\
(0.001)\end{array}$ & $\begin{array}{c}0.358^{* * *} \\
(0.001)\end{array}$ & $\begin{array}{l}0.047^{* * *} \\
(0.001)\end{array}$ & $\begin{array}{c}-0.037^{* * *} \\
(0.002)\end{array}$ & $\begin{array}{l}0.723^{* * *} \\
(0.001)\end{array}$ & $\begin{array}{l}0.239^{* * *} \\
(0.001)\end{array}$ \\
\hline Kinship foster homes & $\begin{array}{c}-2.053^{* * *} \\
(0.053)\end{array}$ & $\begin{array}{c}-0.361^{* * *} \\
(0.006)\end{array}$ & $\begin{array}{c}0.239^{* * *} \\
(0.004)\end{array}$ & $\begin{array}{c}0.576^{* * *} \\
(0.006)\end{array}$ & $\begin{array}{c}-0.017^{* * *} \\
(0.005)\end{array}$ & $\begin{array}{c}0.046^{* * *} \\
(0.011)\end{array}$ & $\begin{array}{l}0.778^{* * *} \\
(0.003)\end{array}$ & $\begin{array}{l}0.212^{* * *} \\
(0.003)\end{array}$ \\
\hline Foster homes & $\begin{array}{c}-2.122^{* * *} \\
(0.043)\end{array}$ & $\begin{array}{c}-0.384^{* * *} \\
(0.005)\end{array}$ & $\begin{array}{c}0.203^{* * *} \\
(0.003)\end{array}$ & $\begin{array}{c}0.567^{* * *} \\
(0.005)\end{array}$ & $\begin{array}{l}-0.008^{*} \\
(0.004)\end{array}$ & $\begin{array}{c}0.064^{* * *} \\
(0.009)\end{array}$ & $\begin{array}{l}0.756^{* * *} \\
(0.003)\end{array}$ & $\begin{array}{l}0.236^{* * *} \\
(0.003)\end{array}$ \\
\hline Enhanced foster homes & $\begin{array}{c}-2.357^{* * *} \\
(0.027)\end{array}$ & $\begin{array}{c}-0.399^{* * *} \\
(0.003)\end{array}$ & $\begin{array}{l}0.243^{* * *} \\
(0.002)\end{array}$ & $\begin{array}{l}0.599^{* * *} \\
(0.003)\end{array}$ & $\begin{array}{l}0.033^{* * *} \\
(0.002)\end{array}$ & $\begin{array}{c}0.008 \\
(0.006)\end{array}$ & $\begin{array}{l}0.735^{* * *} \\
(0.002)\end{array}$ & $\begin{array}{l}0.256^{* * *} \\
(0.002)\end{array}$ \\
\hline MST & $\begin{array}{c}-1.468^{* * *} \\
(0.033)\end{array}$ & $\begin{array}{c}-0.225^{* * *} \\
(0.004)\end{array}$ & $\begin{array}{l}0.126^{* * *} \\
(0.002)\end{array}$ & $\begin{array}{l}0.331^{* * *} \\
(0.004)\end{array}$ & $\begin{array}{c}-0.014^{* * *} \\
(0.003)\end{array}$ & $\begin{array}{c}-0.070^{* * *} \\
(0.007)\end{array}$ & $\begin{array}{l}0.222^{* * *} \\
(0.002)\end{array}$ & $\begin{array}{l}0.758^{* * *} \\
(0.002)\end{array}$ \\
\hline Childcare institutions & $\begin{array}{c}-2.170^{* * *} \\
(0.025)\end{array}$ & $\begin{array}{c}-0.362^{* * *} \\
(0.003)\end{array}$ & $\begin{array}{l}0.214^{* * *} \\
(0.002)\end{array}$ & $\begin{array}{l}0.539^{* * *} \\
(0.003)\end{array}$ & $\begin{array}{l}0.042^{* * *} \\
(0.002)\end{array}$ & $\begin{array}{c}0.010 \\
(0.005)\end{array}$ & $\begin{array}{l}0.490^{* * *} \\
(0.002)\end{array}$ & $\begin{array}{l}0.501^{* * *} \\
(0.001)\end{array}$ \\
\hline \multicolumn{9}{|l|}{ Panel C } \\
\hline Means & 14.364 & 0.570 & 0.034 & 0.098 & 0.045 & 0.487 & 0.066 & 0.029 \\
\hline $\mathrm{N}$ & 860334 & 861518 & 861562 & 861562 & 861562 & 861562 & 861562 & 861562 \\
\hline
\end{tabular}


Moreover, there are large differences in parental characteristics across children in various initiatives (Panel B). These differences reflect a variety of causes; whereas parental neglect and disadvantaged family background are the leading cause for early in-home initiatives and foster homes, child behavioral problems are relatively more important for MST and, to somewhat less degree, childcare institutions.

Most strikingly, children treated with MST have a more advantaged background in terms of parental characteristics than other CWS children with extensive services. For example, while children in various foster homes have parents with close to 40 percentile parental earnings rank lower than the non-CWS children, MST children have parents with earnings at 23 percentile ranks lower. In addition, parents of MST children are very similar to parents of children who receive in-home services only. MST children are also much more likely to be boys, and few have immigrant parents.

\subsection{Criminal charges}

In the next subsections, we describe the life course trajectories of CWS children. While the parents of MST children are comparable to those with in-home services, the children themselves have far more behavioral problems. Children outside of CWS are rarely charged for a felony or a misdemeanor, as shown by Figure 3. However, CWS children are frequently charged, particularly those who have stays in childcare institutions or receive MST, where about 1 in 5 children are charged for a felony at age 16. In contrast, less than 1 in 20 children in various foster homes are charged at age 16. Even if the crime rates taper off after age 18, prevalence remains high until the mid-20s. ${ }^{5}$

\footnotetext{
${ }^{5}$ Children with MST or institutional care have higher criminal charges in all types of categories, but especially high for property crime, violence, drugs, and criminal damage, whereas traffic offense prevalence is more similar (Supplementary Appendix Figure A6).
} 

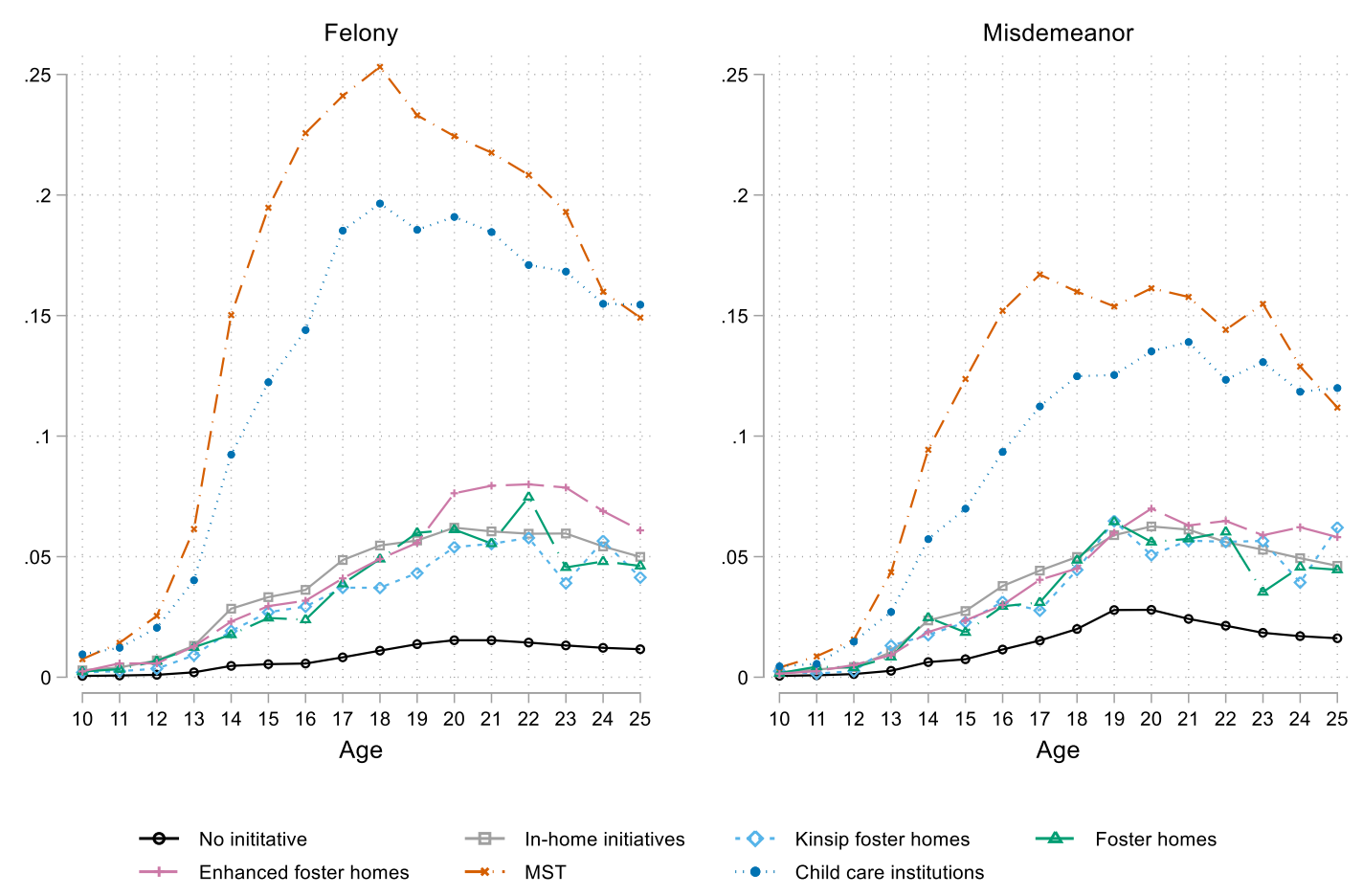

Figure 2: Criminal charges by type of child welfare services.

\subsection{Prescription drugs}

CWS children are more frequently prescribed drugs than other children, and again, children in childcare institutions or receiving MST stand out. At age 15, children outside of CWS are rarely treated with antidepressants. Even if the prevalence is low also among children in childcare institutions and MST children, it is many times larger than in all other groups as almost $5 \%$ is treated with antidepressants. They also have higher levels of anxiolytics, antipsychotics, and hypnotics and sedatives than other children. For example, at age 24, about $14 \%$ use antidepressants, $10 \%$ use anxiolytics, $15 \%$ antipsychotics, and $10 \%$ hypnotics and sedatives. The prevalence of different prescription drugs is about half of those levels among other CWS children and even lower for those outside the CWS.

Also concerning ADHD, CWS children have a markedly higher likelihood of being treated than others. Particularly MST children are likely to be treated for ADHD by centrallyacting sympathomimetics. ADHD drugs are prescribed to about $20 \%$ of MST children at age 15. In comparison, less than $15 \%$ of children in enhanced foster homes and childcare institutions are treated with ADHD drugs, about $10 \%$ of other child welfare children, and only $2 \%$ of children outside child welfare services. 
As with the other life-course trajectories, the striking prescription rate differences may reflect causes for CWS contact and effects of CWS. Since behavioral problems are linked with health issues, the local caseworker may refer CWS children to specialized mental health services for psychiatric diagnosis and treatment, which could explain some of the higher prevalence among some groups.
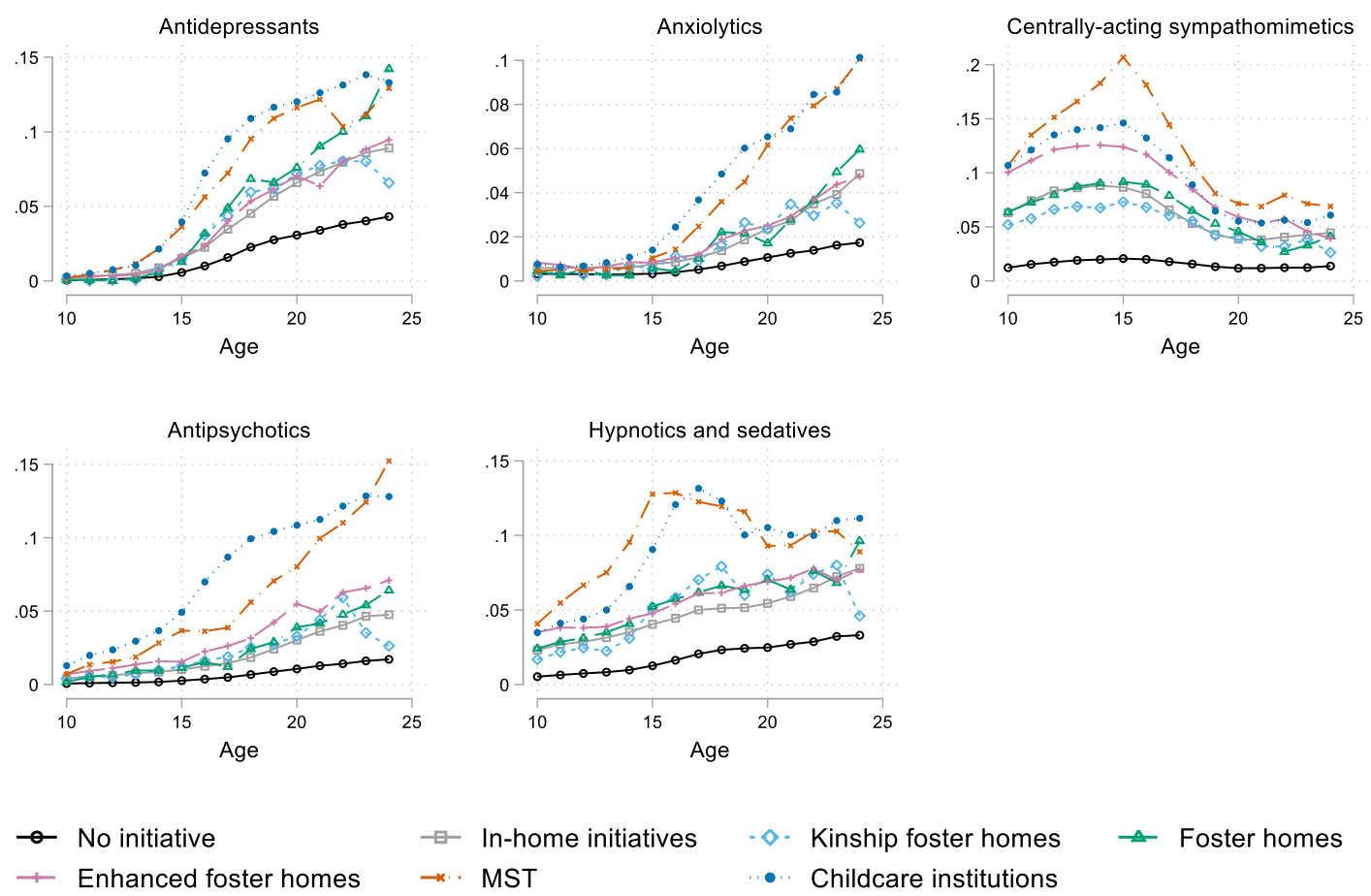

$\begin{array}{ll}- & \text { In-home initiatives } \\ \rightarrow & \quad \text { MST }\end{array}$

$\checkmark$ - Kinship foster homes

-. Childcare institutions

$\triangle$ Foster homes

Figure 3: Prescription drugs by type of child welfare services.

\subsection{Education and labor market exclusion}

Many CWS children struggle at school, often with frequent behavioral problems and low achievement. Before looking at upper secondary completion, let us first check how they do on their 10th-grade school leaving certificate (Table 2). On average, CWS children's GPA is about a standard deviation below that of other children, they are 7.5 percentage points more likely to have poor school behavior, and their school absence is two times that of other children. Like for other outcomes, there is considerable variation among children with CWS contact, and MST children have the least favorable performance. While the GPA of MST children is 1.5 standard deviation lower than for children outside of CWS, the difference is even larger for poor school behavior and absence. 
Table 2: Differences in early school results and school behavior of CWS children compared to other children.

(1) (2) (3)

GPA Poor school behavior Absence hours

\begin{tabular}{lccc}
\hline Panel A & & & \\
No initiative (ref) & & & \\
CWS & $-0.965^{* * *}$ & $0.075^{* * *}$ & $8.536^{* * *}$ \\
& $(0.004)$ & $(0.001)$ & $(0.093)$
\end{tabular}

\section{Panel B}

No initiative (ref)

$\begin{array}{lccc}\text { In-home initiative } & -0.905^{* * *} & 0.061^{* * *} & 7.567^{* * * *} \\ & (0.005) & (0.001) & (0.109) \\ \text { Kinship foster homes } & -0.886^{* * *} & 0.044^{* * *} & 8.079^{* * *} \\ & (0.024) & (0.005) & (0.569) \\ \text { Foster homes } & -0.785^{* * *} & 0.039^{* * *} & 5.308^{* * *} \\ & (0.019) & (0.004) & (0.476) \\ \text { Enhanced foster homes } & -0.850^{* * *} & 0.032^{* * *} & 2.985^{* * *} \\ & (0.013) & (0.003) & (0.297) \\ \text { MST } & -1.551^{* * *} & 0.252^{* * *} & 24.543^{* * *} \\ & (0.015) & (0.003) & (0.362) \\ \text { Childcare institutions } & -1.196^{* * *} & 0.116^{* * *} & 12.084^{* * *} \\ & (0.012) & (0.002) & (0.286)\end{array}$

Panel C

$0.000 \quad 0.022 \quad 9.536$

$\begin{array}{llll}\mathrm{N} & 717334 & 331439 & 377525\end{array}$

Note: Standard errors in parentheses. Panel A compares CWS children with other children, while Panel B distinguishes between various initiatives. Finally, panel $C$ provides the overall means of the outcome variables. ${ }^{*} p<0.05,{ }^{* *} p<0.01,{ }^{* * *} p<0.001$

The inferior school performance of CWS children also shows up in adult attainment. While $80 \%$ of children without CWS complete upper secondary education before age 25 (Figure 4), completion rates are only 40-45\% for children with in-home measures or various foster homes. The large majority of those with childcare institution or MST experience drop out of school early, and only 20\% complete upper secondary education within age 25 .

Childcare institution children and MST children also have a high probability of receiving welfare benefits in their early 20 s. For both groups, about $40 \%$ receive welfare benefits, compared to around $20 \%$ for other CWS children and less than $5 \%$ for those without CWS before age 18. Finally, one in two with childcare institution stays or MST is outside of work and education (NEET) in their mid-20s, suggesting they often experience persistent exclusion. 

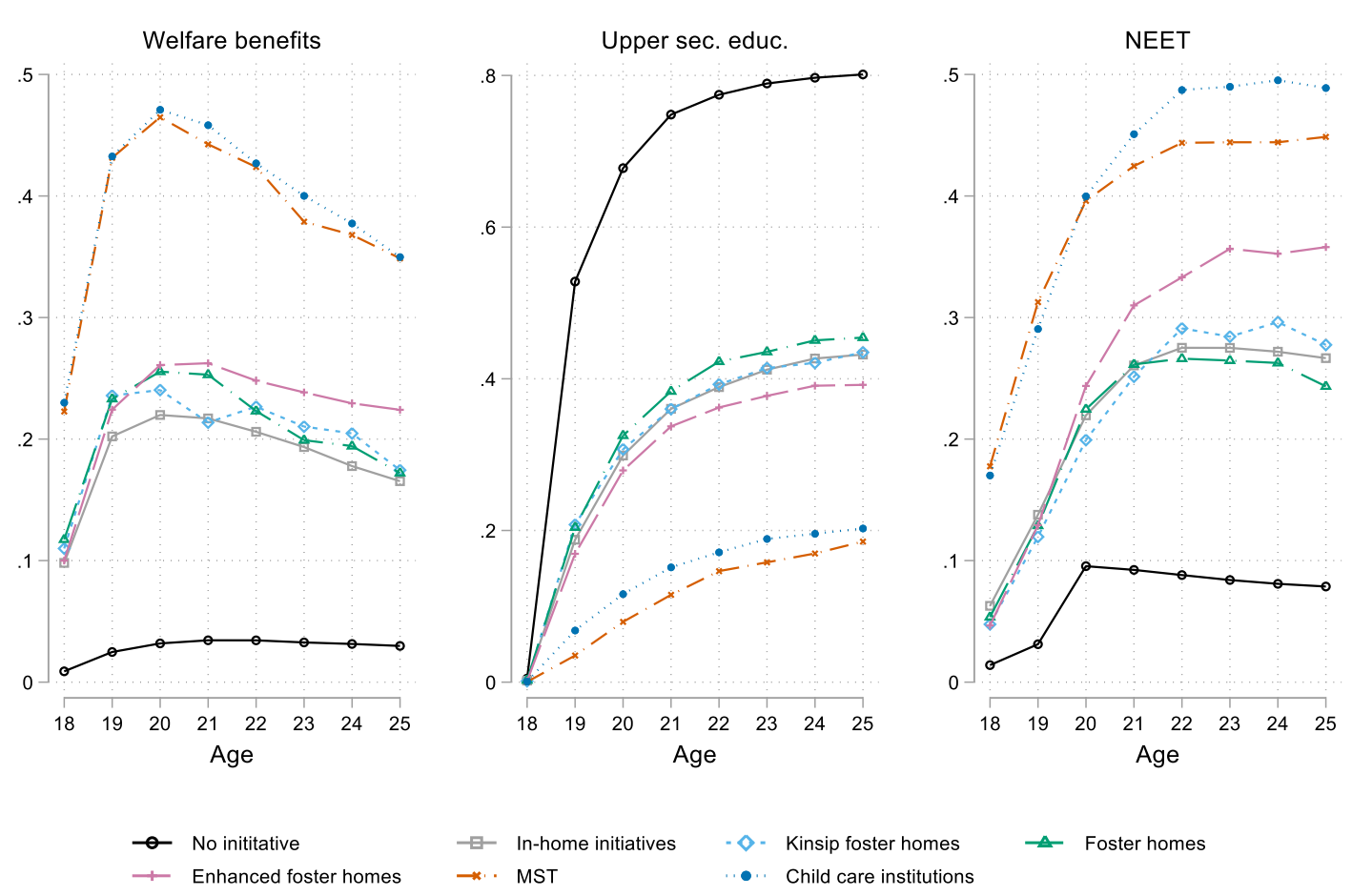

$\begin{array}{lll}\square & \text { In-home initiatives } \quad-\diamond- & \text { Kinsip foster homes } \\ \rightarrow & \text { MST }\end{array}$

Figure 4: Welfare benefits, upper secondary completion, and NEET by type of child welfare services.

\subsection{Adjusted differences}

This section compares the unadjusted CWS coefficients with the corresponding coefficients conditional on gender, birth cohort, and socioeconomic background in similar linear regression models. The changes in coefficients vary with initiative and outcome, as shown graphically in Figure $5 .{ }^{6}$ We have scaled the comparison such that values close to 0 mean no change in coefficient from the unadjusted to the adjusted model, while values close to 100 mean that the coefficients turn zero after adjusting for the control variables. For prescription drugs, especially antipsychotics and antidepressants, the coefficients hardly change after controlling for background characteristics. The lack of explanatory power for parental characteristics suggests the health problems proxied by medication are largely due to child-specific characteristics rather than a problematic family environment.

For the other outcomes, the changes vary by type of CWS initiative. Most strikingly, while the coefficients for foster homes drop considerably, the adverse coefficients for MST

\footnotetext{
${ }^{6}$ All of the regression coefficients are reported in the online appendix (Table A5, Table A6, and Table A7); here, we only present the percent change in the coefficient from the unadjusted to the adjusted model.
} 
children remain largely unaffected after controlling for background characteristics. For example, the background characteristics lead to a $60-70 \%$ drop in the outcome differential between the foster home and non-CWS children. In contrast, the MST coefficient only drops by $22 \%$. One takeaway from these results is that the problem behavior of MST is largely unrelated to their family socioeconomic resources, suggesting sorting into this treatment based on harder-to-observe individual-level risk factors.

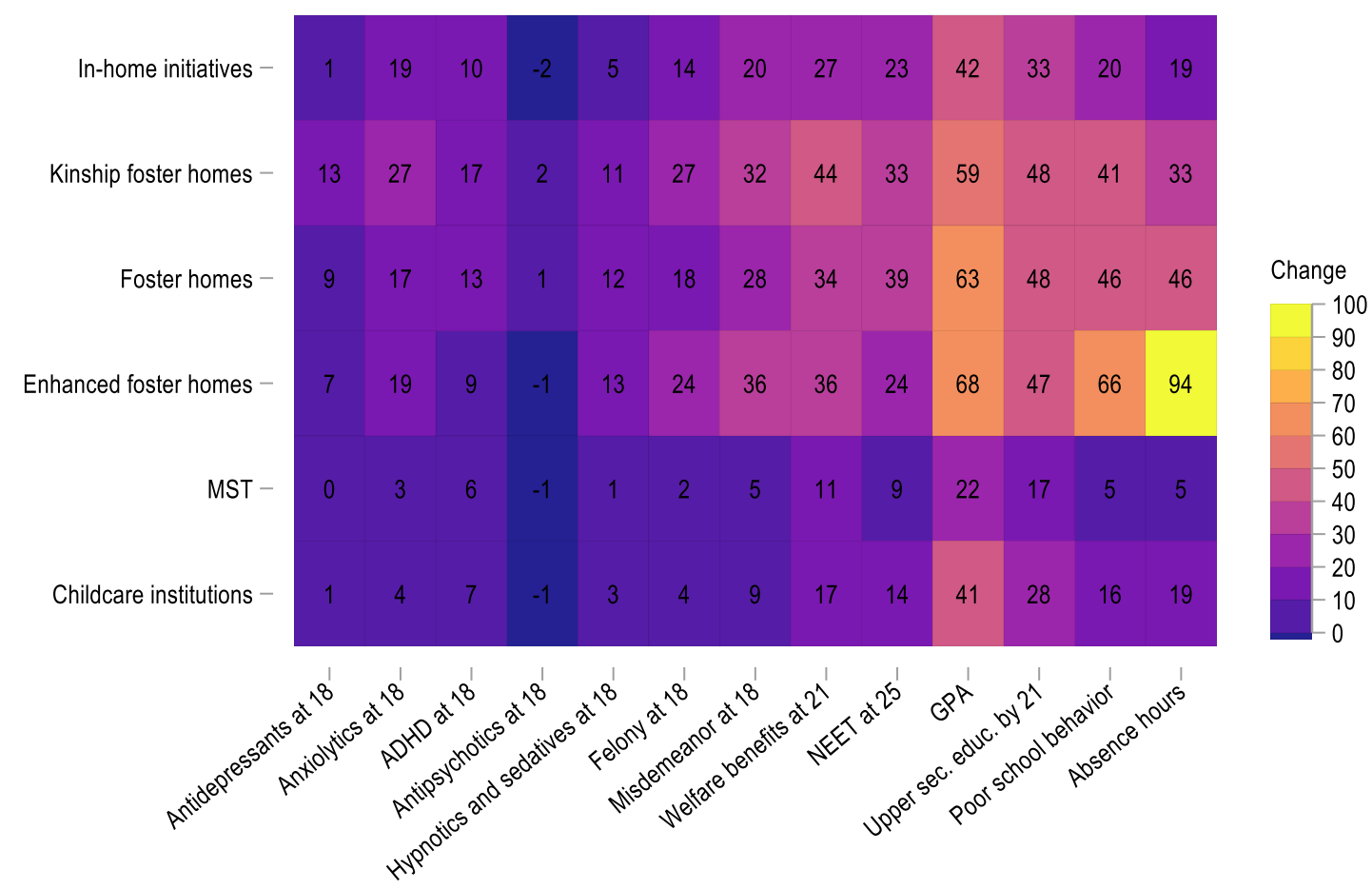

Figure 5: Percent change in coefficients after controlling for background characteristics.

Note: The unadjusted models include no control variables, while the adjusted models control for parental education, parental earnings, parental welfare benefits, parental crime, immigrant background, and dummies for birth cohort. The change from the unadjusted $\left(\beta_{j}^{1}\right)$ to the adjusted $\left(\beta_{j}^{2}\right)$ coefficient for variable $j$ in Table A5, Table A6, and Table A7 are divided by the unadjusted coefficients in the same tables: $\left(\beta_{j}^{1}-\beta_{j}^{2}\right) / \beta_{j}^{1}$. Values close to 0 mean no change in coefficient from the unadjusted to the adjusted model, while values close to 100 mean that the coefficients turn 0 after adjusting for the control variables.

\section{Discussion}

CWS children constitute a heterogeneous group with dispersed family background characteristics and life-course patterns. In Norway, every tenth child is in contact with CWS before 18; however, the characteristics and life-course patterns vary considerably. From a bird's eye view, we can distinguish between three broad groups of CWS children. First, the 
majority of CWS children receive in-home services like counseling, financial assistance, and support groups (excluding MST), often for a short period during childhood. Compared to children outside CWS, they have disadvantaged socioeconomic backgrounds, and they have more frequent criminal charges, a higher prevalence of prescribed drugs for mental health and ADHD, and less favorable school performance.

A second group is a small group of children who have lived in various types of foster homes. Unsurprisingly, these children have lower socioeconomic backgrounds than children receiving in-home measures. Nevertheless, their life-course patterns largely resemble the patterns of children receiving in-home measures. Although children in enhanced foster homes, which are used for children with high levels of problem behavior, have less favorable outcomes than other foster home children, the differences are small compared to MST and childcare institution children.

Finally, the CWS children with experience from childcare institutions or MST have severe behavioral problems, and their life course prospects are considerably less favorable than what we find for other child welfare children. A large fraction are charged for criminal activity already in early adolescence, and they continue to be in frequent contact with the police into adulthood. Moreover, many are treated for ADHD and mental health problems. Just one in five complete upper secondary education, and one in two experience persisting labor market exclusion.

Still, despite similar life course trajectories, childcare institution children and MST children differ in one important aspect; while institutionalized children's parents often have few resources, the socioeconomic background of MST children is relatively high compared to other CWS children. Typically, the children who receive MST enter CWS late, primarily because of their own behavioral problems and rarely because of parental neglect.

This sorting into MST illustrates the complex relationship between individual characteristics and family environment in causing behavioral and academic problems. Knowledge of unique sorting processes into various child welfare initiatives is needed for studies that aim to evaluate the effectiveness of CWS initiatives. For example, MST clients exhibit strong indicators of problem behavior, as indicated in our study by the frequency of police charges, academic failure, truancy, school dropout, and mental health problems. Family background variables cannot explain these background factors. Thus, studies investigating the effectiveness of MST by adjusting for family background only (e.g., Dæhlen 
and Madsen 2016) are likely to be biased because of unobserved individual-level confounders.

\section{References}

Ask, Helga, Marte Handal, Lars Johan Hauge, Ted Reichborn-Kjennerud, and Svetlana Skurtveit. 2019. "Incidence of Diagnosed Pediatric Anxiety Disorders and Use of Prescription Drugs: A Nation-Wide Registry Study." European child \& adolescent psychiatry:1-11.

Bald, Anthony, Eric Chyn, Justine S. Hastings, and Margarita Machelett. 2019. "The Causal Impact of Removing Children from Abusive and Neglectful Homes."

Bebbington, Andrew, and John Miles. 1989. "The Background of Children Who Enter Local Authority Care." The British Journal of Social Work 19(5):349-368.

Berger, Lawrence M. 2004. "Income, Family Structure, and Child Maltreatment Risk." Children and Youth Services Review 26(8):725-748.

Berrick, Jill, Jonathan Dickens, Tarja Pösö, and Marit Skivenes. 2017. "A Cross-Country Comparison of Child Welfare Systems and Workers' Responses to Children Appearing to Be at Risk or in Need of Help." Child Abuse Review 26(4):305-319.

Brännström, Lars, Hilma Forsman, Bo Vinnerljung, and Ylva B Almquist. 2017. "The Truly Disadvantaged? Midlife Outcome Dynamics of Individuals with Experiences of out-of-Home Care." Child abuse \& neglect 67:408-418.

Doyle Jr, Joseph J. 2007. "Child Protection and Child Outcomes: Measuring the Effects of Foster Care." American Economic Review 97(5):1583-1610.

Doyle Jr, Joseph J. 2008. "Child Protection and Adult Crime: Using Investigator Assignment to Estimate Causal Effects of Foster Care." Journal of political Economy 116(4):746-770.

Dæhlen, Marianne, and Christian Madsen. 2016. "School Enrolment Following Multisystemic Treatment: A Register-Based Examination among Youth with Severe Behavioural Problems." Children and Youth Services Review 67:76-83.

Franzén, Eva, Bo Vinnerljung, and Anders Hjern. 2007. "The Epidemiology of out-of-Home Care for Children and Youth: A National Cohort Study." The British Journal of Social Work 38(6):10431059.

Gilbert, Neil. 2012. "A Comparative Study of Child Welfare Systems: Abstract Orientations and Concrete Results." Children and Youth Services Review 34(3):532-536.

Jozefiak, Thomas, Nanna Sønnichsen Kayed, Tormod Rimehaug, Anne Kristine Wormdal, Ann Mari Brubakk, and Lars Wichstrøm. 2016. "Prevalence and Comorbidity of Mental Disorders among Adolescents Living in Residential Youth Care." European Child \& Adolescent Psychiatry 25(1):33-47.

Langford, Malcolm, Marit Skivenes, and Karl Harald Søvig. 2019. Children's Rights in Norway. An Implementation Paradox? Universitetsforlaget.

Lindsey, Duncan. 1991. "Factors Affecting the Foster Care Placement Decision: An Analysis of National Survey Data." American Journal of Orthopsychiatry 61(2):272-281.

Lindsey, Duncan. 1992. "Adequacy of Income and the Foster Care Placement Decision: Using an Odds Ratio Approach to Examine Client Variables." Pp. 29-36 in Social Work Research and Abstracts. Oxford University Press.

Pelton, Leroy H. 2015. "The Continuing Role of Material Factors in Child Maltreatment and Placement." Child Abuse \& Neglect 41:30-39.

Skurtveit, S., J. G. Bramness, V. Hjellvik, I. Hartz, R. Nesvåg, L. J. Hauge, and M. Handal. 2018. "Increase in Diagnosis of Depressive Disorders Contributes to the Increase in Antidepressant Use in Adolescents." Acta Psychiatrica Scandinavica 137(5):413-421. 
Vinnerljung, Bo, Anders Hjern, and Frank Lindblad. 2006. "Suicide Attempts and Severe Psychiatric Morbidity among Former Child Welfare Clients - a National Cohort Study." Journal of Child Psychology and Psychiatry 47(7):723-733.

Vinnerljung, Bo, Maria Öman, and Thomas Gunnarson. 2005. "Educational Attainments of Former Child Welfare Clients - a Swedish National Cohort Study." International Journal of Social Welfare 14(4):265-276.

Wesselhoeft, Rikke, Peter Bjødstrup Jensen, Ardesheer Talati, Johan Reutfors, Kari Furu, Katrine Strandberg - Larsen, Per Damkier, Anton Pottegård, and Mette Bliddal. 2020. "Trends in Antidepressant Use among Children and Adolescents: A Scandinavian Drug Utilization Study." Acta Psychiatrica Scandinavica 141(1):34-42.

Wong, Jenna, Aude Motulsky, Tewodros Eguale, David L. Buckeridge, Michal Abrahamowicz, and Robyn Tamblyn. 2016. "Treatment Indications for Antidepressants Prescribed in Primary Care in Quebec, Canada, 2006-2015." Jama 315(20):2230-2232. 


\title{
Supplementary Online Appendix
}

\section{Every tenth child: \\ Heterogeneity in characteristics and life-course patterns among children in contact with child welfare services}

\author{
Nicolai T. Borgen ${ }^{1}$, Ivar Frønes ${ }^{2,3}$, and Oddbjørn Raaum ${ }^{4}$ \\ ${ }^{1}$ Department of Special Needs Education, University of Oslo \\ ${ }^{2}$ Norwegian Center for Child Behavioral Development \\ ${ }^{3}$ Department of Sociology and Human Geography, University of Oslo \\ ${ }^{4}$ The Ragnar Frisch Centre for Economic Research, Norway
}

Content of supplementary online appendix:

Online Appendix A: Supplementary tables and figures

Online Appendix B: Life-course patterns by child welfare service initiatives for birth cohorts 1992-1995

Online Appendix C: Life-course patterns by age at contact 
Online Appendix A: Supplementary tables and figures

Table A1: Sample characteristics

\begin{tabular}{llllll}
\hline & N & Mean & SD & Min & Max \\
\hline Welfare benefits at 25 & 223201 & 0.046 & 0.209 & 0 & 1 \\
Crim. charge by 25 & 164310 & 0.241 & 0.427 & 0 & 1 \\
Crim. charge at 25 & 164310 & 0.031 & 0.174 & 0 & 1 \\
Upper sec. educ. by 25 & 223201 & 0.763 & 0.425 & 0 & 1 \\
NEET at 25 & 218383 & 0.100 & 0.300 & 0 & 1 \\
Grade point average (10th grade) & 717493 & 40.129 & 8.228 & 10 & 60 \\
Poor behavior (10th grade) & 331439 & 0.022 & 0.146 & 0 & 1 \\
Absence hours (8-10th grade) & 377525 & 9.536 & 17.428 & 0 & 806 \\
Absence days (8-10th grade) & 376281 & 11.400 & 16.711 & 0 & 803 \\
Gender & 861562 & 0.487 & 0.500 & 0 & 1 \\
Year of birth & 861562 & 1994.045 & 4.271 & 1987 & 2001 \\
Parental neglect & 861562 & 0.066 & 0.248 & 0 & 1 \\
Child behavioral problems & 861562 & 0.029 & 0.169 & 0 & 1 \\
Parents education & 860334 & 14.364 & 2.414 & 7 & 21 \\
Parents ranked earnings & 861518 & 0.570 & 0.275 & 0 & .99 \\
Parents felony & 861562 & 0.034 & 0.182 & 0 & 1 \\
Parents welfare benefits & 861562 & 0.098 & 0.297 & 0 & 1 \\
Children of immigrants & 861562 & 0.045 & 0.208 & 0 & 1 \\
\hline
\end{tabular}

Table A2: Share with a given initiative that receives other initiatives throughout childhood.

\begin{tabular}{lllllll}
\hline & 1 & 2 & 3 & 4 & 5 & 6 \\
\hline 1. In-home initiatives & 1.00 & 0.05 & 0.09 & 0.11 & 0.04 & 0.11 \\
2. Kinship Foster homes & 0.81 & 1.00 & 0.30 & 0.39 & 0.03 & 0.18 \\
3. Foster homes & 0.80 & 0.17 & 1.00 & 0.57 & 0.04 & 0.25 \\
4. Enhanced foster homes & 0.82 & 0.17 & 0.47 & 1.00 & 0.05 & 0.31 \\
5. MST & 0.67 & 0.03 & 0.07 & 0.10 & 1.00 & 0.26 \\
6. Childcare institutions & 0.79 & 0.08 & 0.21 & 0.31 & 0.12 & 1.00 \\
\hline
\end{tabular}

Note: Birth cohorts 1992-1995. Only the most extensive initiative is recorded each year. 
Table A3: Birth cohort coverage for variables.

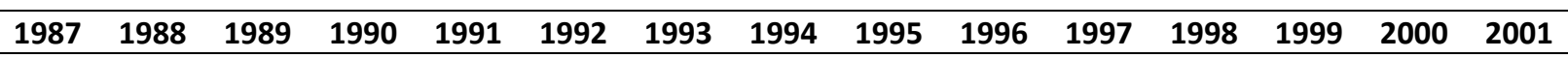

\begin{tabular}{|c|c|c|c|c|c|c|c|c|c|c|c|c|c|c|c|}
\hline \multicolumn{16}{|l|}{ Background characteristics } \\
\hline Parental earnings & $x$ & $x$ & $x$ & $x$ & $x$ & $x$ & $x$ & $x$ & $x$ & $x$ & $x$ & $x$ & $x$ & $x$ & $x$ \\
\hline Parental education & $x$ & $x$ & $x$ & $x$ & $x$ & $x$ & $x$ & $x$ & $x$ & $x$ & $x$ & $x$ & $x$ & $x$ & $x$ \\
\hline Parental welfare benefits & $x$ & $x$ & $x$ & $x$ & $x$ & $x$ & $x$ & $x$ & $x$ & $x$ & $x$ & $x$ & $x$ & $x$ & $x$ \\
\hline Parental felony & $x$ & $x$ & $x$ & $x$ & $x$ & $x$ & $x$ & $x$ & $x$ & $x$ & $x$ & $x$ & $x$ & $x$ & $x$ \\
\hline Gender & $x$ & $x$ & $x$ & $x$ & $x$ & $x$ & $x$ & $x$ & $x$ & $x$ & $x$ & $x$ & $x$ & $x$ & $x$ \\
\hline & 1987 & 1988 & 1989 & 1990 & 1991 & 1992 & 1993 & 1994 & 1995 & 1996 & 1997 & 1998 & 1999 & 2000 & 2001 \\
\hline
\end{tabular}

\begin{tabular}{|c|c|c|c|c|c|c|c|c|c|c|c|c|c|c|c|}
\hline \multicolumn{16}{|c|}{ Child welfare services } \\
\hline Age 1 & & & & & & & $x$ & $x$ & $x$ & $x$ & $x$ & $x$ & $x$ & $x$ & $x$ \\
\hline Age 2 & & & & & & $x$ & $x$ & $x$ & $x$ & $x$ & $x$ & $x$ & $x$ & $x$ & $x$ \\
\hline Age 3 & & & & & $x$ & $x$ & $x$ & $x$ & $x$ & $x$ & $x$ & $x$ & $x$ & $x$ & $x$ \\
\hline Age 4 & & & & $x$ & $x$ & $x$ & $x$ & $x$ & $x$ & $x$ & $x$ & $x$ & $x$ & $x$ & $x$ \\
\hline Age 5 & & & $x$ & $x$ & $x$ & $x$ & $x$ & $x$ & $x$ & $x$ & $x$ & $x$ & $x$ & $x$ & $x$ \\
\hline Age 6 & & $x$ & $x$ & $x$ & $x$ & $x$ & $x$ & $x$ & $x$ & $x$ & $x$ & $x$ & $x$ & $x$ & $x$ \\
\hline Age 7 & $x$ & $x$ & $x$ & $x$ & $x$ & $x$ & $x$ & $x$ & $x$ & $x$ & $x$ & $x$ & $x$ & $x$ & $x$ \\
\hline Age 8 & $x$ & $x$ & $x$ & $x$ & $x$ & $x$ & $x$ & $x$ & $x$ & $x$ & $x$ & $x$ & $x$ & $x$ & $x$ \\
\hline Age 9 & $x$ & $x$ & $x$ & $x$ & $x$ & $x$ & $x$ & $x$ & $x$ & $x$ & $x$ & $x$ & $x$ & $x$ & $x$ \\
\hline Age 10 & $x$ & $x$ & $x$ & $x$ & $x$ & $x$ & $x$ & $x$ & $x$ & $x$ & $x$ & $x$ & $x$ & $x$ & $x$ \\
\hline Age 11 & $x$ & $x$ & $x$ & $x$ & $x$ & $x$ & $x$ & $x$ & $x$ & $x$ & $x$ & $x$ & $x$ & $x$ & $x$ \\
\hline Age 12 & $x$ & $x$ & $x$ & $x$ & $x$ & $x$ & $x$ & $x$ & $x$ & $x$ & $x$ & $x$ & $x$ & $x$ & \\
\hline Age 13 & $x$ & $x$ & $x$ & $x$ & $x$ & $x$ & $x$ & $x$ & $x$ & $x$ & $x$ & $x$ & $x$ & & \\
\hline Age 14 & $x$ & $x$ & $x$ & $x$ & $x$ & $x$ & $x$ & $x$ & $x$ & $x$ & $x$ & $x$ & & & \\
\hline Age 15 & $x$ & $x$ & $x$ & $x$ & $x$ & $x$ & $x$ & $x$ & $x$ & $x$ & $x$ & & & & \\
\hline Age 16 & $x$ & $x$ & $x$ & $x$ & $x$ & $x$ & $x$ & $x$ & $x$ & $x$ & & & & & \\
\hline Age 17 & $x$ & $x$ & $x$ & $x$ & $x$ & $x$ & $x$ & $x$ & $x$ & & & & & & \\
\hline \multirow[t]{2}{*}{ Age 18} & $x$ & $x$ & $x$ & $x$ & $x$ & $x$ & $x$ & $x$ & & & & & & & \\
\hline & 1987 & 1988 & 1989 & 1990 & 1991 & 1992 & 1993 & 1994 & 1995 & 1996 & 1997 & 1998 & 1999 & 2000 & 2001 \\
\hline
\end{tabular}


School leaving certificate

School behavior

School absence

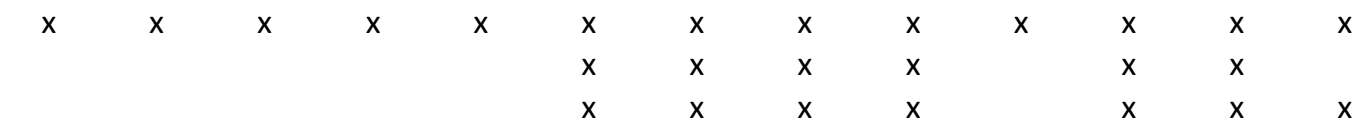

\begin{tabular}{|c|c|c|c|c|c|c|c|c|c|c|c|c|c|c|c|}
\hline & 1987 & 1988 & 1989 & 1990 & 1991 & 1992 & 1993 & 1994 & 1995 & 1996 & 1997 & 1998 & 1999 & 2000 & 2001 \\
\hline \multicolumn{16}{|c|}{ Upper secondary education } \\
\hline Age 18 & $\mathrm{x}$ & $\mathrm{x}$ & $\mathrm{x}$ & $\mathrm{x}$ & $\mathrm{x}$ & $\mathrm{x}$ & $\mathrm{x}$ & $\mathrm{x}$ & $\mathrm{x}$ & $\mathrm{x}$ & $\mathrm{x}$ & & & & \\
\hline Age 19 & $\mathrm{x}$ & $\mathrm{x}$ & $\mathrm{x}$ & $\mathrm{x}$ & $\mathrm{x}$ & $\mathrm{x}$ & $\mathrm{x}$ & $\mathrm{x}$ & $\mathrm{x}$ & $\mathrm{x}$ & & & & & \\
\hline Age 20 & $\mathrm{x}$ & $\mathrm{x}$ & $\mathrm{x}$ & $\mathrm{x}$ & $\mathrm{x}$ & $\mathrm{x}$ & $\mathrm{x}$ & $\mathrm{x}$ & $\mathrm{x}$ & & & & & & \\
\hline Age 21 & $\mathrm{x}$ & $\mathrm{x}$ & $\mathrm{x}$ & $\mathrm{x}$ & $\mathrm{x}$ & $\mathrm{x}$ & $\mathrm{x}$ & $\mathrm{x}$ & & & & & & & \\
\hline Age 22 & $\mathrm{x}$ & $\mathrm{x}$ & $\mathrm{x}$ & $\mathrm{x}$ & $\mathrm{x}$ & $\mathrm{x}$ & $\mathrm{x}$ & & & & & & & & \\
\hline Age 23 & $\mathrm{x}$ & $\mathrm{x}$ & $\mathrm{x}$ & $\mathrm{x}$ & $\mathrm{x}$ & $\mathrm{x}$ & & & & & & & & & \\
\hline Age 24 & $\mathrm{x}$ & $\mathrm{x}$ & $\mathrm{x}$ & $\mathrm{x}$ & $\mathrm{x}$ & & & & & & & & & & \\
\hline \multirow[t]{2}{*}{ Age 25} & $\mathrm{x}$ & $\mathrm{x}$ & $\mathrm{x}$ & $\mathrm{x}$ & & & & & & & & & & & \\
\hline & 1987 & 1988 & 1989 & 1990 & 1991 & 1992 & 1993 & 1994 & 1995 & 1996 & 1997 & 1998 & 1999 & 2000 & 2001 \\
\hline
\end{tabular}

Criminal charge

Age 10

Age 11

Age 12

Age 13

Age 14

Age 15

Age 16

Age 17

Age 18

Age 19

Age 20

Age 21

Age 22

Age 23

Age 24

Age 25

\begin{tabular}{|c|c|c|c|c|c|c|c|c|c|c|c|c|c|}
\hline$x$ & $x$ & $x$ & $x$ & $x$ & $x$ & $x$ & $x$ & $x$ & $x$ & $x$ & $x$ & $x$ & $x$ \\
\hline$x$ & $x$ & $x$ & $x$ & $x$ & $x$ & $x$ & $x$ & $x$ & $x$ & $x$ & $x$ & $x$ & $x$ \\
\hline$x$ & $x$ & $x$ & $x$ & $x$ & $x$ & $x$ & $x$ & $x$ & $x$ & $x$ & $x$ & $x$ & $x$ \\
\hline$x$ & $x$ & $x$ & $x$ & $x$ & $x$ & $x$ & $x$ & $x$ & $x$ & $x$ & $x$ & $x$ & $x$ \\
\hline$x$ & $x$ & $x$ & $x$ & $x$ & $x$ & $x$ & $x$ & $x$ & $x$ & $x$ & $x$ & $x$ & $x$ \\
\hline$x$ & $x$ & $x$ & $x$ & $x$ & $x$ & $x$ & $x$ & $x$ & $x$ & $x$ & $x$ & $x$ & \\
\hline$x$ & $x$ & $x$ & $x$ & $x$ & $x$ & $x$ & $x$ & $x$ & $x$ & $x$ & $x$ & & \\
\hline$x$ & $x$ & $x$ & $x$ & $x$ & $x$ & $x$ & $x$ & $x$ & $x$ & $x$ & & & \\
\hline$x$ & $x$ & $x$ & $x$ & $x$ & $x$ & $x$ & $x$ & $x$ & $x$ & & & & \\
\hline$x$ & $x$ & $x$ & $x$ & $x$ & $x$ & $x$ & $x$ & $x$ & & & & & \\
\hline$x$ & $x$ & $x$ & $x$ & $x$ & $x$ & $x$ & $x$ & & & & & & \\
\hline$x$ & $x$ & $x$ & $x$ & $x$ & $x$ & $x$ & & & & & & & \\
\hline$x$ & $x$ & $x$ & $x$ & $x$ & $x$ & & & & & & & & \\
\hline$x$ & $x$ & $x$ & $x$ & $x$ & & & & & & & & & \\
\hline$x$ & $x$ & $x$ & $x$ & & & & & & & & & & \\
\hline$x$ & $x$ & $x$ & & & & & & & & & & & \\
\hline
\end{tabular}


\begin{tabular}{lllllllllllllll}
1987 & 1988 & 1989 & 1990 & 1991 & 1992 & 1993 & 1994 & 1995 & 1996 & 1997 & 1998 & 1999 & 2000 & 2001 \\
\hline
\end{tabular}

\begin{tabular}{|c|c|c|c|c|c|c|c|c|c|c|c|c|c|c|c|}
\hline \multicolumn{16}{|c|}{ Welfare benefits } \\
\hline Age 18 & $\mathrm{x}$ & $x$ & $\mathrm{x}$ & $\mathrm{x}$ & $\mathrm{x}$ & $\mathrm{x}$ & $\mathrm{x}$ & $\mathrm{x}$ & $\mathrm{x}$ & $\mathrm{x}$ & \multicolumn{5}{|l|}{$x$} \\
\hline Age 19 & $\mathrm{x}$ & $\mathrm{x}$ & $\mathrm{x}$ & $\mathrm{x}$ & $\mathrm{x}$ & $\mathrm{x}$ & $\mathrm{x}$ & $\mathrm{x}$ & $\mathrm{x}$ & $\mathrm{x}$ & & & & & \\
\hline Age 20 & $\mathrm{x}$ & $x$ & $x$ & $\mathrm{x}$ & $\mathrm{x}$ & $\mathrm{x}$ & $\mathrm{x}$ & $\mathrm{x}$ & $\mathrm{x}$ & & & & & & \\
\hline Age 21 & $\mathrm{x}$ & $\mathrm{x}$ & $\mathrm{x}$ & $\mathrm{x}$ & $\mathrm{x}$ & $\mathrm{x}$ & $\mathrm{x}$ & $\mathrm{x}$ & & & & & & & \\
\hline Age 22 & $x$ & $\mathrm{x}$ & $\mathrm{x}$ & $\mathrm{x}$ & $\mathrm{x}$ & $\mathrm{x}$ & $\mathrm{x}$ & & & & & & & & \\
\hline Age 23 & $\mathrm{x}$ & $\mathrm{x}$ & $\mathrm{x}$ & $\mathrm{x}$ & $\mathrm{x}$ & $\mathrm{x}$ & & & & & & & & & \\
\hline Age 24 & $\mathrm{x}$ & $x$ & $\mathrm{x}$ & $\mathrm{x}$ & $\mathrm{x}$ & & & & & & & & & & \\
\hline \multirow[t]{2}{*}{ Age 25} & $x$ & $x$ & $x$ & $x$ & & & & & & & & & & & \\
\hline & 1987 & 1988 & 1989 & 1990 & 1991 & 1992 & 1993 & 1994 & 1995 & 1996 & 1997 & 1998 & 1999 & 2000 & 2001 \\
\hline \multicolumn{16}{|c|}{ Prescription drugs } \\
\hline Age 10 & & & & & & & & $\mathrm{x}$ & $\mathrm{x}$ & $\mathrm{x}$ & $\mathrm{x}$ & $\mathrm{x}$ & $\mathrm{x}$ & $\mathrm{x}$ & $\mathrm{x}$ \\
\hline Age 11 & & & & & & & & $\mathrm{x}$ & $\mathrm{x}$ & $\mathrm{x}$ & $\mathrm{x}$ & $\mathrm{x}$ & $\mathrm{x}$ & $\mathrm{x}$ & $\mathrm{x}$ \\
\hline Age 12 & & & & & & & & $\mathrm{x}$ & $\mathrm{x}$ & $\mathrm{x}$ & $\mathrm{x}$ & $\mathrm{x}$ & $\mathrm{x}$ & $\mathrm{x}$ & $\mathrm{x}$ \\
\hline Age 13 & & & & & & & & $\mathrm{x}$ & $\mathrm{x}$ & $\mathrm{x}$ & $\mathrm{x}$ & $\mathrm{x}$ & $\mathrm{x}$ & $\mathrm{x}$ & $\mathrm{x}$ \\
\hline Age 14 & & & & & & & & $\mathrm{x}$ & $\mathrm{x}$ & $\mathrm{x}$ & $\mathrm{x}$ & $\mathrm{x}$ & $\mathrm{x}$ & $\mathrm{x}$ & $\mathrm{x}$ \\
\hline Age 15 & & & & & & & & $\mathrm{x}$ & $\mathrm{x}$ & $\mathrm{x}$ & $\mathrm{x}$ & $\mathrm{x}$ & $\mathrm{x}$ & $\mathrm{x}$ & $\mathrm{x}$ \\
\hline Age 16 & & & & & & & & $\mathrm{x}$ & $\mathrm{x}$ & $\mathrm{x}$ & $\mathrm{x}$ & $\mathrm{x}$ & $\mathrm{x}$ & $\mathrm{x}$ & $\mathrm{x}$ \\
\hline Age 17 & & & & & & & & $\mathrm{x}$ & $\mathrm{x}$ & $\mathrm{x}$ & $\mathrm{x}$ & $\mathrm{x}$ & $\mathrm{x}$ & $\mathrm{x}$ & $\mathrm{x}$ \\
\hline Age 18 & & & & & & & & $\mathrm{x}$ & $\mathrm{x}$ & $\mathrm{x}$ & $\mathrm{x}$ & $\mathrm{x}$ & $\mathrm{x}$ & $\mathrm{x}$ & \\
\hline Age 19 & & & & & & & & $\mathrm{x}$ & $x$ & $x$ & $x$ & $x$ & $x$ & & \\
\hline Age 20 & & & & & & & & $x$ & $x$ & $x$ & $x$ & $x$ & & & \\
\hline Age 21 & & & & & & & & $x$ & $x$ & $x$ & $x$ & & & & \\
\hline Age 22 & & & & & & & & $x$ & $x$ & $x$ & & & & & \\
\hline Age 23 & & & & & & & & $x$ & $x$ & & & & & & \\
\hline Age 24 & & & & & & & & $x$ & & & & & & & \\
\hline
\end{tabular}


Table A4: Unadjusted and adjusted differences in absence days. Panel A compares CWS children with other children, while Panel B distinguishes between various types of initiatives. Panel $\mathrm{C}$ provides the overall mean of absence days.

(1) (2)

Absence days

\begin{tabular}{lll}
\hline Panel A & & \\
No initiative (ref) & & \\
CWS & $8.359^{* * *}$ & $6.456^{* * *}$ \\
& $(0.089)$ & $(0.101)$
\end{tabular}

Panel B

No initiative (ref)

In-home initiative

$8.175^{* * *} \quad 6.433^{* * *}$

$(0.105) \quad(0.112)$

Kinship foster homes

$7.353^{* * *} \quad 4.120^{* * * *}$

$(0.548) \quad(0.548)$

Foster homes $\quad 5.543^{* * *} \quad 2.379^{* * *}$

$(0.457) \quad(0.459)$

Enhanced foster homes $2.216^{* * *} \quad-1.063^{* * *}$

(0.286) $\quad(0.293)$

MST $18.399^{* * *} 16.639^{* * * *}$

$(0.348) \quad(0.347)$

Childcare institutions $10.422^{* * *} \quad 7.680^{* * * *}$

(0.276) $\quad(0.282)$

Panel C

Means

11.400

Control variables No $\quad$ Yes

\begin{tabular}{lll} 
N & 376281 & 375853 \\
\hline
\end{tabular}

Note: Standard errors in parentheses. Control variables are parental education, parental earnings, parental welfare benefits, parental crime, immigrant background, and dummies for birth cohort.

${ }^{*} p<0.05,{ }^{* *} p<0.01,{ }^{* * *} p<0.001$ 
Table A5: Unadjusted and adjusted early school results and school behavior of CWS children compared to other children. Panel A compares CWS children with other children, while Panel $B$ distinguishes between various initiatives. Panel $C$ provides the overall means of the outcome variables.
(1)
(2)
(3)
(4)
(5)
(6)

\begin{tabular}{lcccccc} 
& \multicolumn{2}{c}{ GPA } & \multicolumn{2}{c}{ Poor school behavior } & \multicolumn{2}{c}{ Absence hours } \\
\hline $\begin{array}{l}\text { Panel A } \\
\text { No initiative (ref) }\end{array}$ & & & & & & \\
CWS & $-0.965^{* * *}$ & $-0.558^{* * *}$ & $0.075^{* * *}$ & $0.062^{* * *}$ & $8.536^{* * *}$ & $6.957^{* * *}$ \\
& $(0.004)$ & $(0.004)$ & $(0.001)$ & $(0.001)$ & $(0.093)$ & $(0.105)$
\end{tabular}

\section{Panel B}

No initiative (ref)

In-home initiative

$-0.905^{* * *}$

$-0.525^{* * *}$

$0.061^{* * *}$

$0.049^{* * *}$

$7.567^{* * *}$

$6.117^{* * *}$

$\begin{array}{ll}(0.005) \quad(0.004) & 0.0359\end{array}$

$(0.001)$

(0.001)

(0.109)

(0.117)

Kinship foster homes

$-0.886^{* * *}$

$-0.359^{* * *}$

$0.044^{* * *}$

$0.026^{* * *}$

$8.079^{* * *}$

$5.439^{* * * *}$

(0.024)

$(0.022)$

$(0.005)$

(0.005)

$(0.569)$

(0.570)

Foster homes

$-0.785^{\circ}$

$-0.290^{* * * *}$

$0.039^{* * *}$

$0.021^{\text {**** }}$

$5.308^{* * * *}$

$2.850^{* * * * *}$

Enhanced foster homes

$-0.850^{* * *}$

(0.017)

(0.004)

(0.004)

(0.476)

(0.478)

$0.032^{* * *}$

$0.011^{* * *}$

$2.985^{* * *}$

0.189

$\begin{array}{ll}(0.013) & (0.012)\end{array}$

$(0.003)$

$(0.003)$

(0.297)

$-1.551^{* * *}-1.204^{* * * *}$

$0.252^{* * * *}$

$0.239^{* * *}$

$24.543^{* * * *}$

(0.305)

MST

$(0.015)$

(0.013)

Childcare institutions

$-1.196^{* * *}$

$-0.707^{* * *}$

(0.003)

(0.003)

(0.362)

$23.341^{* * * *}$

(0.012)

(0.011)

$0.116^{* * *}$

$0.098^{* * *}$

$12.084^{* * *}$

(0.362)

(0.002)

(0.003)

(0.286)

$9.763^{* * *}$

(0.293)

\section{Panel C}

Means

0.000

0.022

9.536

$\begin{array}{lllllll}\text { Control variables } & \text { No } & \text { Yes } & \text { No } & \text { Yes } & \text { No } & \text { Yes }\end{array}$

N $\quad 717334 \quad 716650 \quad 331439 \quad 331073 \quad 377525 \quad 377096$

Note: Standard errors in parentheses. Panel A compares CWS children with other children, while Panel B distinguishes between various initiatives. Panel $\mathrm{C}$ provides the overall means of the outcome variables. Control variables are parental education, parental earnings, parental welfare benefits, parental crime, immigrant background, and dummies for birth cohort. Appendix Table A4 shows results for absence days. ${ }^{*} p<0.05,{ }^{* *} p<0.01,{ }^{* * *} p<0.001$ 
Table A6: Unadjusted and adjusted crime, welfare benefits, upper secondary education completion, and NEET of CWS children compared to other children.

\begin{tabular}{|c|c|c|c|c|c|c|c|c|c|c|}
\hline \multirow{2}{*}{ Panel A } & \multirow{2}{*}{ (1) $\mathrm{F}$} & \multirow[t]{2}{*}{ (2) } & \multirow{2}{*}{\multicolumn{2}{|c|}{$\begin{array}{l}\text { (3) } \\
\text { Misdemeanor } \\
\text { at } 18\end{array}$}} & \multirow{2}{*}{\multicolumn{2}{|c|}{$\begin{array}{l}\text { (5) } \\
\text { Welfare benefits } \\
\text { at } 21\end{array}$}} & \multirow{2}{*}{\multicolumn{2}{|c|}{$\begin{array}{l}(7) \\
\text { Upper sec. educ. } \\
\text { by } 21\end{array}$}} & (9) & (10) \\
\hline & & & & & & & & & \multicolumn{2}{|c|}{$\begin{array}{l}\text { NEET } \\
\text { by } 25 \\
\end{array}$} \\
\hline $\begin{array}{l}\text { No Initiative (ret) } \\
\text { CWS }\end{array}$ & $\begin{array}{l}0.073^{* * *} \\
(0.001)\end{array}$ & $\begin{array}{l}0.066^{* * *} \\
(0.001)\end{array}$ & $\begin{array}{l}0.046^{* * *} \\
(0.001)\end{array}$ & $\begin{array}{l}0.039^{* * *} \\
(0.001)\end{array}$ & $\begin{array}{l}0.232^{* * *} \\
(0.001)\end{array}$ & $\begin{array}{l}0.175^{* * *} \\
(0.001)\end{array}$ & $\begin{array}{c}-0.431^{* * *} \\
(0.002)\end{array}$ & $\begin{array}{c}-0.291^{* * *} \\
(0.002)\end{array}$ & $\begin{array}{l}0.234^{\text {*** }} \\
(0.002)\end{array}$ & $\begin{array}{l}0.185^{\text {*** }} \\
(0.002)\end{array}$ \\
\hline \multicolumn{11}{|l|}{$\begin{array}{l}\text { Panel B } \\
\text { No initiative (ref) }\end{array}$} \\
\hline In-home initiative & $\begin{array}{l}0.044^{* * *} \\
(0.001)\end{array}$ & $\begin{array}{l}0.038^{* * *} \\
(0.001)\end{array}$ & $\begin{array}{l}0.030^{* * *} \\
(0.001)\end{array}$ & $\begin{array}{l}0.024^{* * *} \\
(0.001)\end{array}$ & $\begin{array}{l}0.183^{* * *} \\
(0.001)\end{array}$ & $\begin{array}{l}0.133^{* * *} \\
(0.001)\end{array}$ & $\begin{array}{c}-0.388^{* * *} \\
(0.003)\end{array}$ & $\begin{array}{c}-0.259^{* * *} \\
(0.003)\end{array}$ & $\begin{array}{c}0.188^{* * *} \\
(0.003)\end{array}$ & $\begin{array}{l}0.144^{\text {*** }} \\
(0.003)\end{array}$ \\
\hline Kinship foster homes & $\begin{array}{l}0.026^{* * *} \\
(0.004)\end{array}$ & $\begin{array}{l}0.019^{* * *} \\
(0.004)\end{array}$ & $\begin{array}{l}0.025^{* * *} \\
(0.004)\end{array}$ & $\begin{array}{l}0.017^{* * *} \\
(0.004)\end{array}$ & $\begin{array}{l}0.179^{* * *} \\
(0.007)\end{array}$ & $\begin{array}{l}0.100^{* * *} \\
(0.007)\end{array}$ & $\begin{array}{c}-0.388^{* * *} \\
(0.014)\end{array}$ & $\begin{array}{c}-0.203^{* * *} \\
(0.014)\end{array}$ & $\begin{array}{c}0.199^{* * *} \\
(0.015)\end{array}$ & $\begin{array}{l}0.134^{* * *} \\
(0.015)\end{array}$ \\
\hline Foster homes & $\begin{array}{l}0.038^{* * *} \\
(0.003)\end{array}$ & $\begin{array}{l}0.031^{* * *} \\
(0.003)\end{array}$ & $\begin{array}{l}0.029^{* * *} \\
(0.003)\end{array}$ & $\begin{array}{l}0.021^{* * *} \\
(0.003)\end{array}$ & $\begin{array}{l}0.219^{* * *} \\
(0.005)\end{array}$ & $\begin{array}{l}0.144^{* * *} \\
(0.005)\end{array}$ & $\begin{array}{c}-0.365^{\text {*** }} \\
(0.010)\end{array}$ & $\begin{array}{c}-0.191^{* * *} \\
(0.010)\end{array}$ & $\begin{array}{l}0.165^{\text {*** }} \\
(0.010)\end{array}$ & $\begin{array}{c}0.100^{\text {**** }} \\
(0.010)\end{array}$ \\
\hline Enhanced foster homes & $\begin{array}{l}0.038^{* * *} \\
(0.002)\end{array}$ & $\begin{array}{l}0.029^{* * *} \\
(0.002)\end{array}$ & $\begin{array}{l}0.025^{* * *} \\
(0.002)\end{array}$ & $\begin{array}{l}0.016^{* * *} \\
(0.002)\end{array}$ & $\begin{array}{c}0.228^{* * *} \\
(0.004)\end{array}$ & $\begin{array}{l}0.147^{* * *} \\
(0.004)\end{array}$ & $\begin{array}{l}-0.411^{* * * *} \\
(0.007)\end{array}$ & $\begin{array}{l}-0.216^{* * * *} \\
(0.007)\end{array}$ & $\begin{array}{c}0.279^{* * * *} \\
(0.008)\end{array}$ & $\begin{array}{l}0.213^{* * *} \\
(0.008)\end{array}$ \\
\hline MST & $\begin{array}{l}0.242^{* * *} \\
(0.002)\end{array}$ & $\begin{array}{l}0.236^{* * * *} \\
(0.002)\end{array}$ & $\begin{array}{l}0.140^{* * * *} \\
(0.002)\end{array}$ & $\begin{array}{l}0.133^{* * *} \\
(0.002)\end{array}$ & $\begin{array}{l}0.408^{* * *} \\
(0.004)\end{array}$ & $\begin{array}{l}0.364^{* * *} \\
(0.004)\end{array}$ & $\begin{array}{c}-0.633^{\text {*** }} \\
(0.008)\end{array}$ & $\begin{array}{c}-0.523^{\text {*** }} \\
(0.008)\end{array}$ & $\begin{array}{c}0.370^{* * *} \\
(0.008)\end{array}$ & $\begin{array}{c}0.335^{\text {*** }} \\
(0.008)\end{array}$ \\
\hline Childcare institutions & $\begin{array}{c}0.185^{* * *} \\
(0.002)\end{array}$ & $\begin{array}{c}0.177^{* * *} \\
(0.002)\end{array}$ & $\begin{array}{c}0.105^{* * *} \\
(0.002)\end{array}$ & $\begin{array}{c}0.096^{* * *} \\
(0.002)\end{array}$ & $\begin{array}{c}0.424^{* * *} \\
(0.003)\end{array}$ & $\begin{array}{c}0.354^{* * *} \\
(0.003)\end{array}$ & $\begin{array}{c}-0.597^{* * *} \\
(0.006)\end{array}$ & $\begin{array}{c}-0.427^{* * * *} \\
(0.006)\end{array}$ & $\begin{array}{c}0.410^{* * * *} \\
(0.006)\end{array}$ & $\begin{array}{c}0.353^{\text {*** }} \\
(0.006)\end{array}$ \\
\hline \multicolumn{11}{|l|}{ Panel C } \\
\hline Means & & & & & & & & & & \\
\hline $\begin{array}{l}\text { Control variables } \\
\mathrm{N}\end{array}$ & $\begin{array}{c}\text { No } \\
574980\end{array}$ & $\begin{array}{c}\text { Yes } \\
574187\end{array}$ & $\begin{array}{c}\text { No } \\
574980\end{array}$ & $\begin{array}{c}\text { Yes } \\
574187\end{array}$ & $\begin{array}{c}\text { No } \\
456855\end{array}$ & $\begin{array}{c}\text { Yes } \\
456204\end{array}$ & $\begin{array}{c}\text { No } \\
456855\end{array}$ & $\begin{array}{c}\text { Yes } \\
456204\end{array}$ & $\begin{array}{c}\text { No } \\
218383 \\
\end{array}$ & $\begin{array}{c}\text { Yes } \\
218143\end{array}$ \\
\hline
\end{tabular}


Table A7: Unadjusted and adjusted prescription drug rates of CWS children compared to other children.

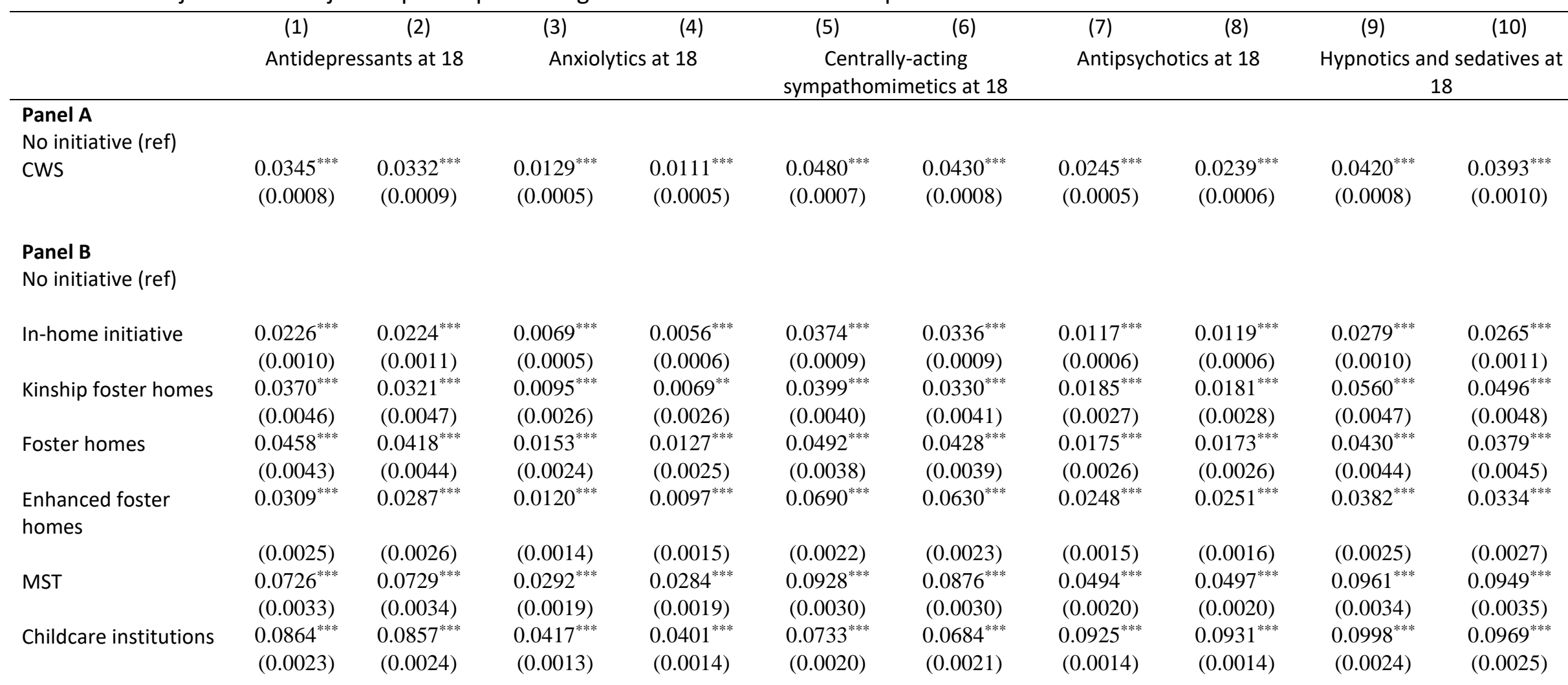

\section{Panel C}

Means

0.0262

0.0081

0.0205

0.0093

0.0276

Control variables

$\begin{array}{cccccccc}\text { No } & \text { Yes } & \text { No } & \text { Yes } & \text { No } & \text { Yes } & \text { No } & \text { Yes } \\ 418726 & 406827 & 418726 & 406827 & 418726 & 406827 & 418726 & 406827\end{array}$

418726

406827

Note: Standard errors in parentheses. Panel A compares CWS children with other children, while Panel B distinguishes between various types of initiatives. Panel C provides overall means of the variables. Control variables are parental education, parental earnings, parental welfare benefits, immigrant background, and dummies for birth cohort. ${ }^{*} p<0.05,{ }^{* *} p<0.01,{ }^{* * *} p<0.001$ 

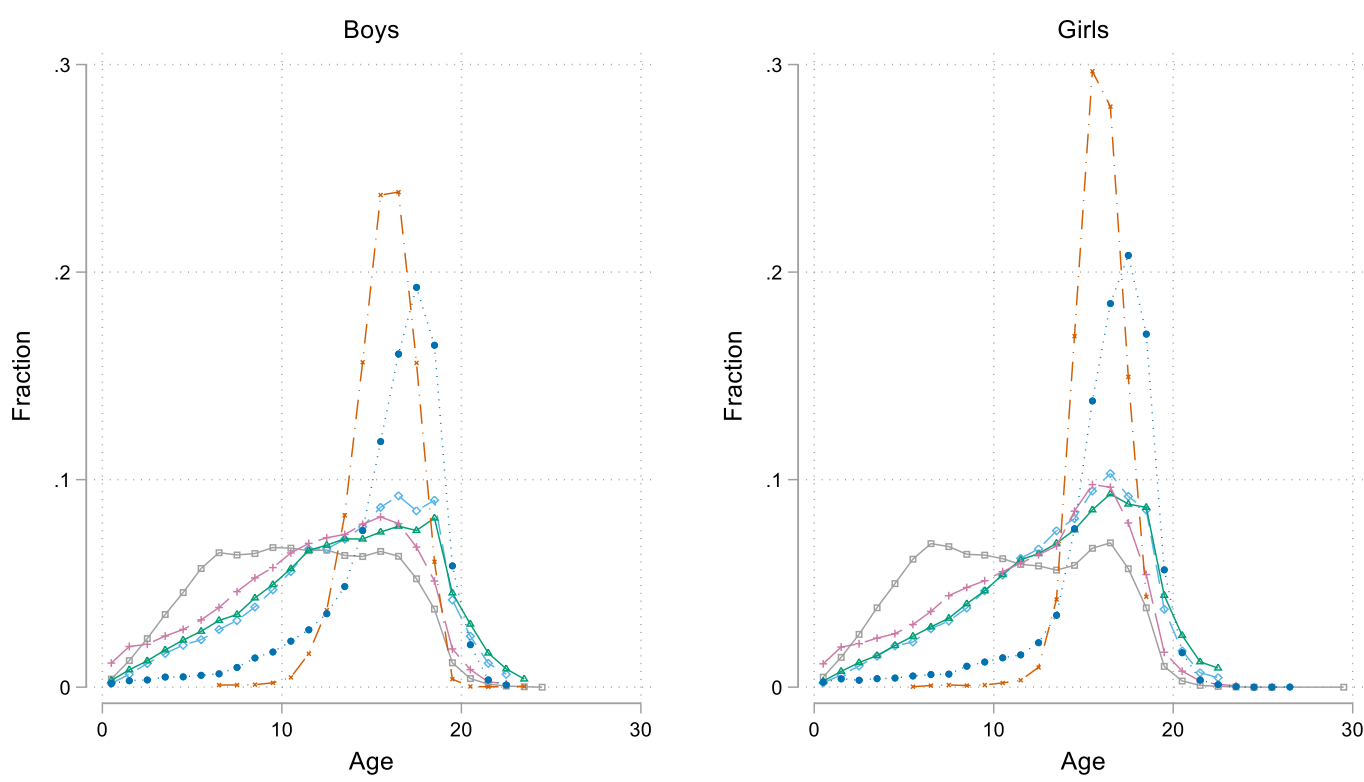

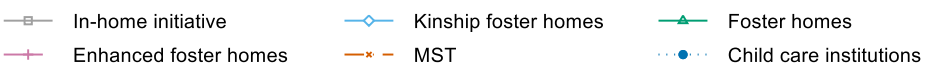

Figure A1: Gender differences in age peaks of child welfare measures.

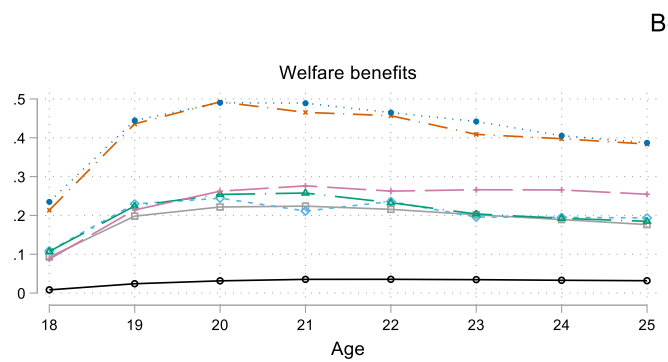

Boys

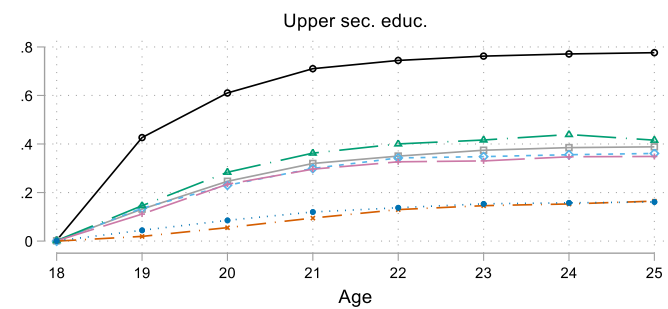

Girls
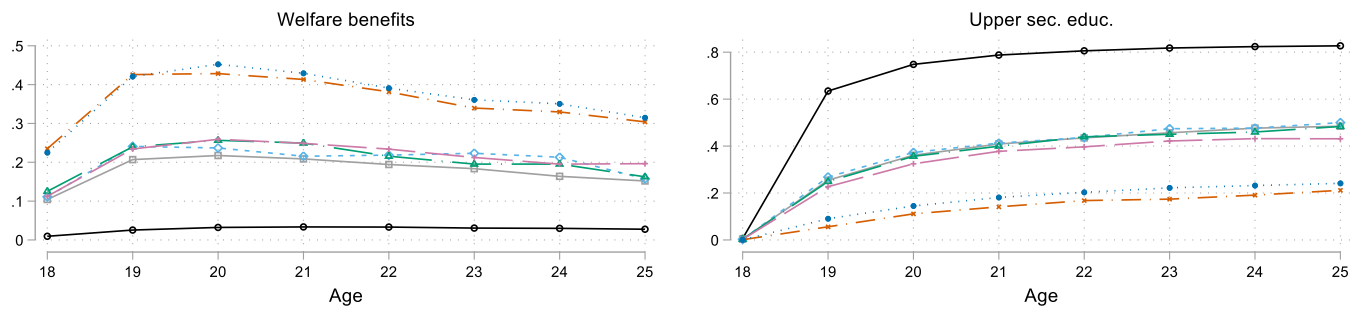

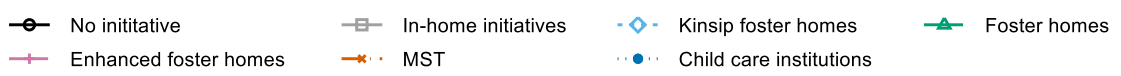

Figure A2: Completion of upper secondary education and welfare benefits by gender. 
Boys
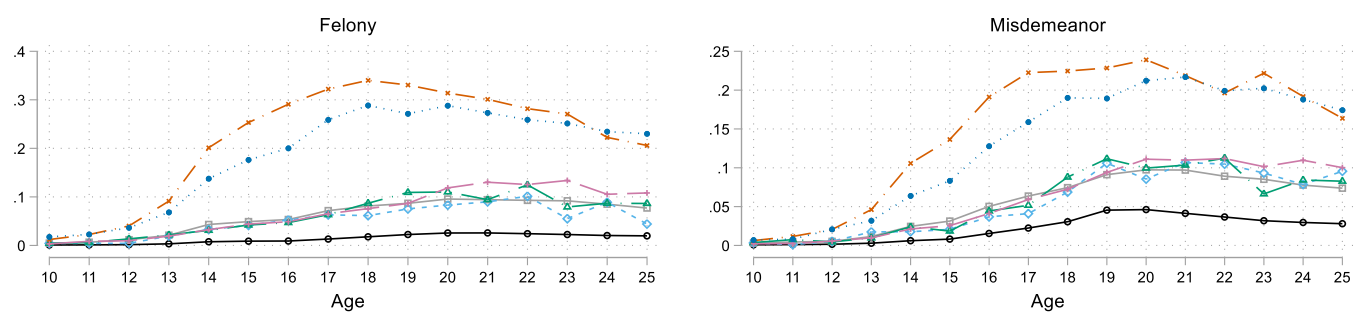

Girls
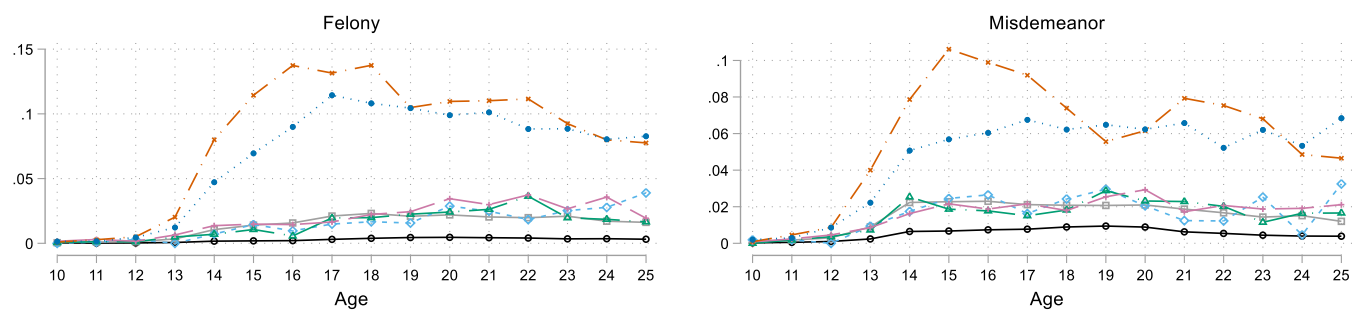

$\rightarrow$ No inititative $\quad \square$ In-home initiatives

$\longrightarrow$ Enhanced foster homes $\rightarrow$ MST

- Kinsip foster homes $\quad \longrightarrow$ Foster homes

-. Child care institutions

Figure A3: Criminal charges by gender.
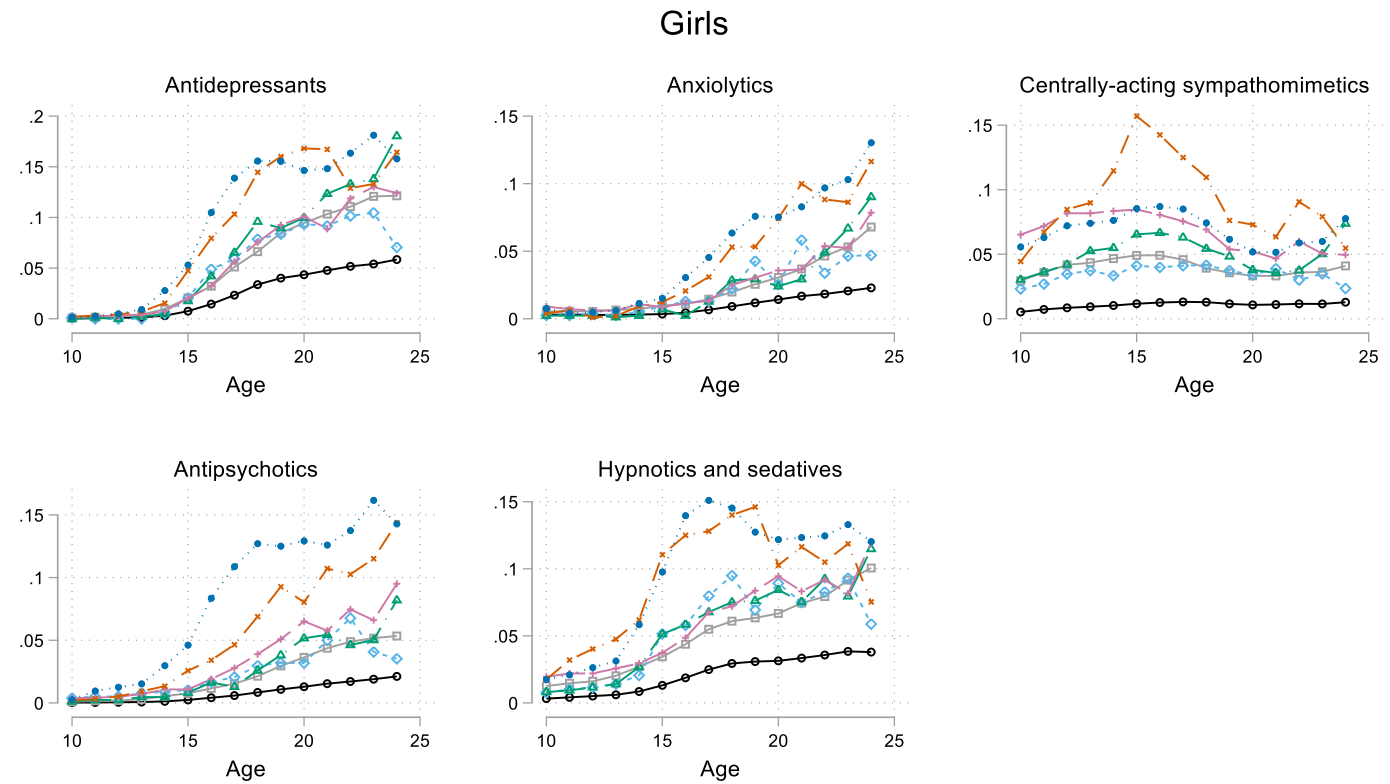

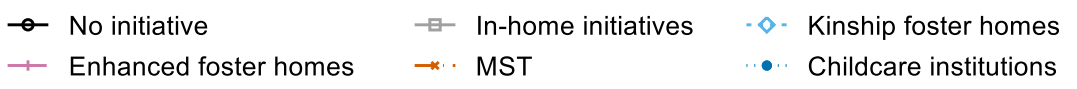

Figure A4: Prescription drugs for girls. 


\section{Boys}
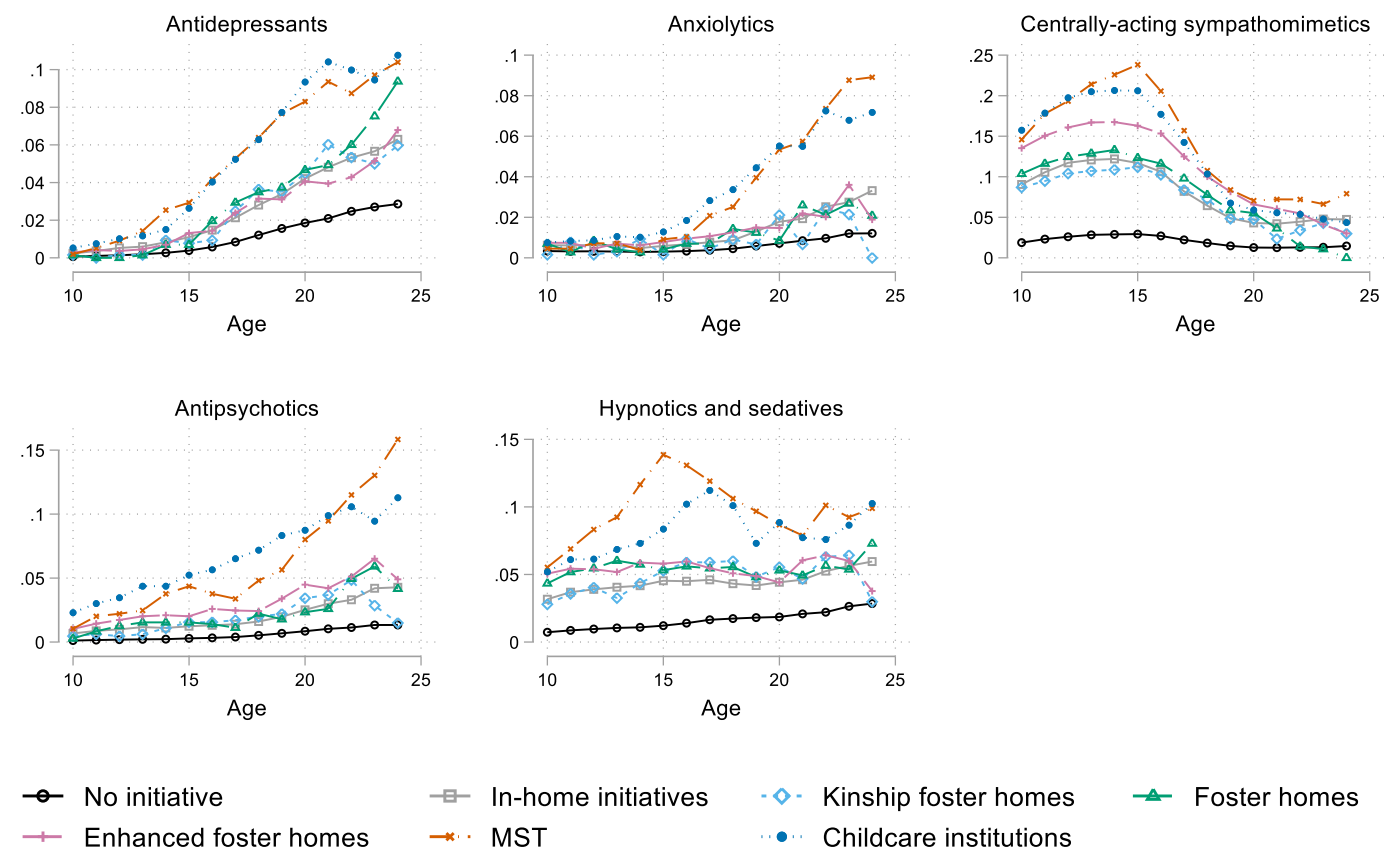
$\because$ In-home initiatives
*. MST

- Kinship foster homes
-. Childcare institutions

$\triangle$ Foster homes

Figure A5: Prescription drugs for boys. 

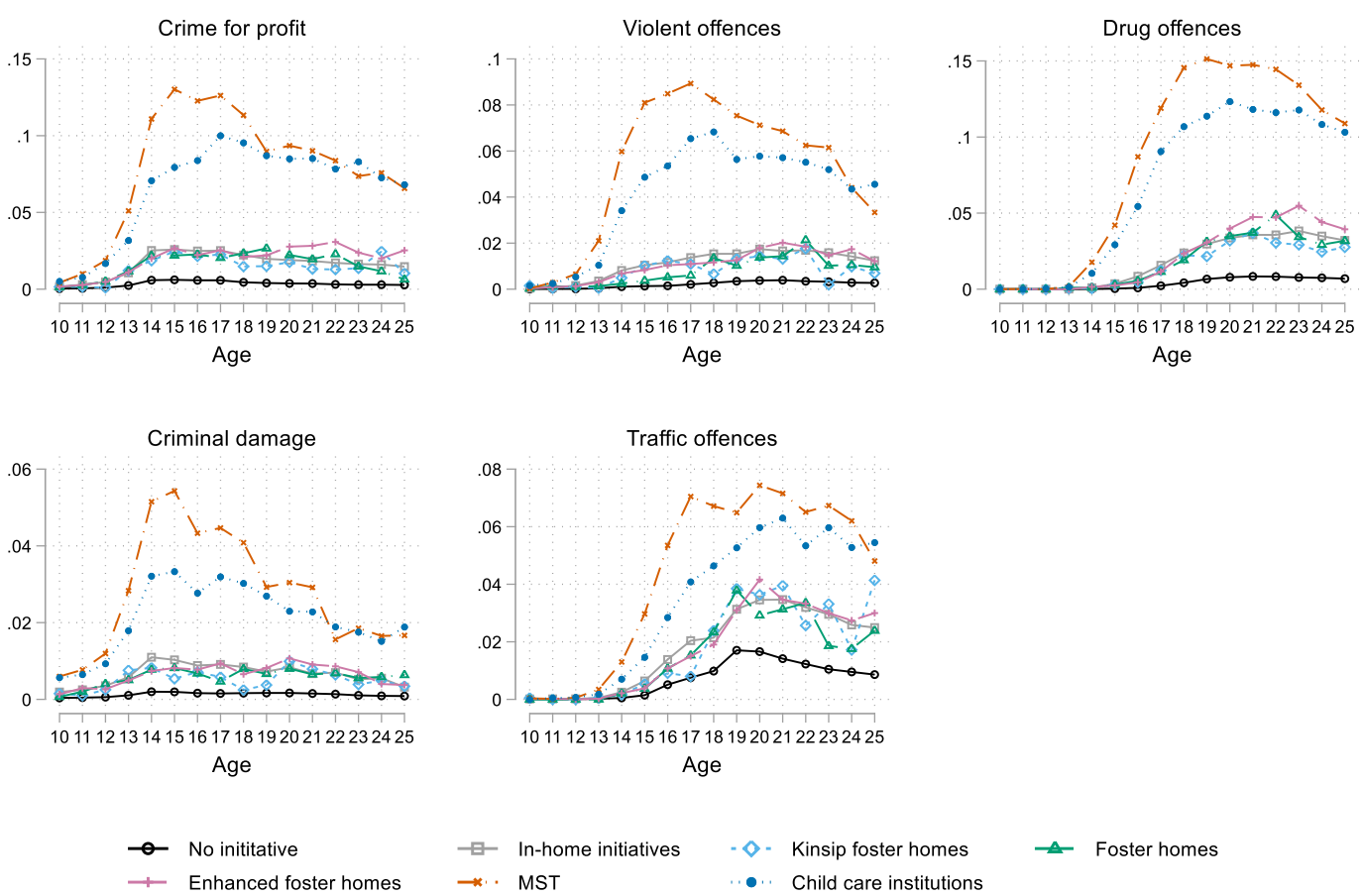

Figure A6: Differences between various types of criminal charges

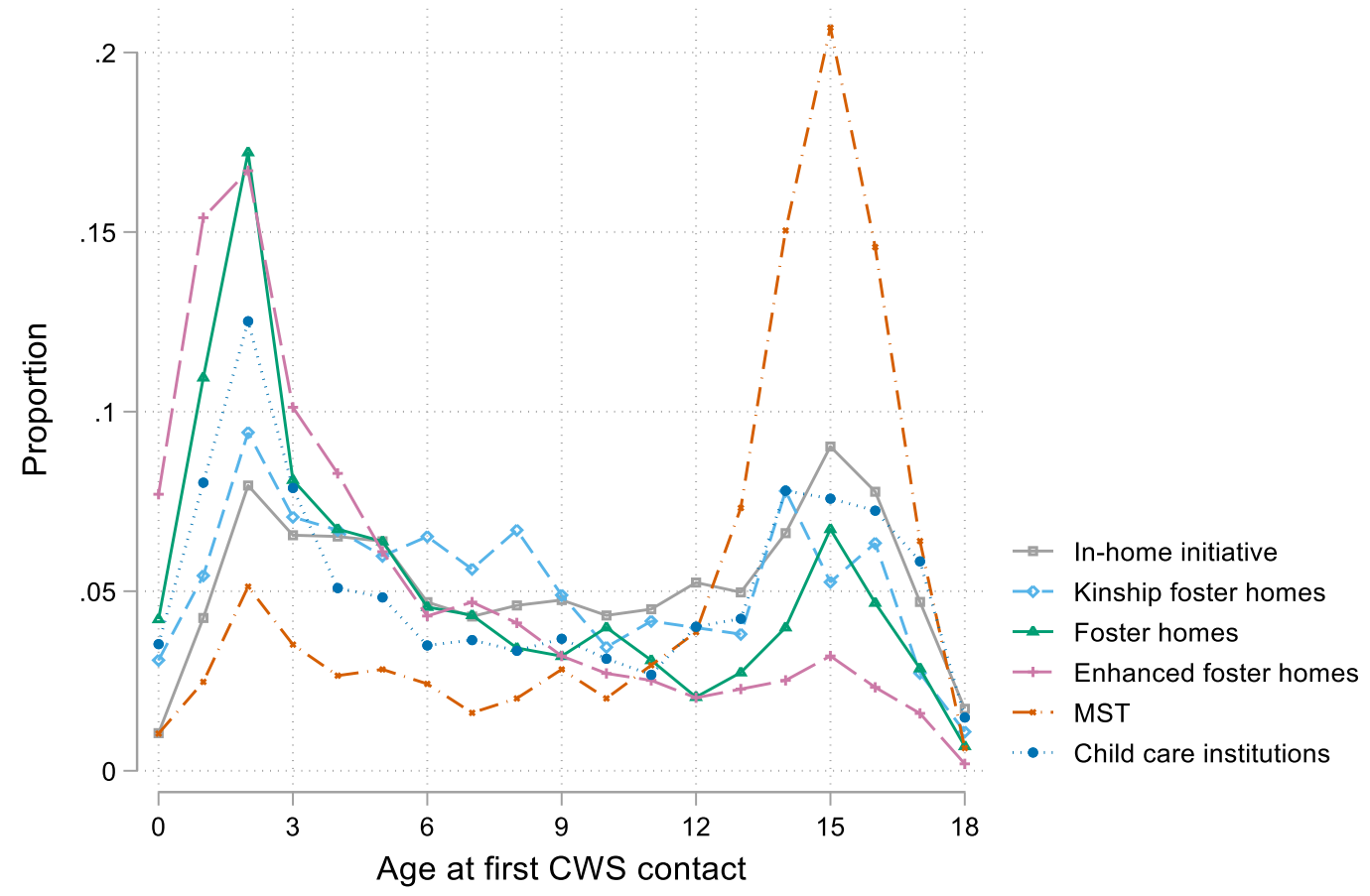

Figure A7: Age at first CWS contact for birth cohorts 1992-1995. 


\section{Online Appendix B: Life-course patterns by child welfare service initiative for birth cohorts 1992-1995}

This online appendix restricts the sample to birth cohorts 1992-1995, where we can observe nearly complete child welfare services histories. The 1993 and 1994 cohorts can be observed from ages 1-18, while cohorts 1992 and 1995 can be observed from ages 2-18 and 1-17. Because of the birth cohort restriction, we cannot follow children until age 25 on all variables. See Appendix Table A3 for more details about birth cohort coverage rates.

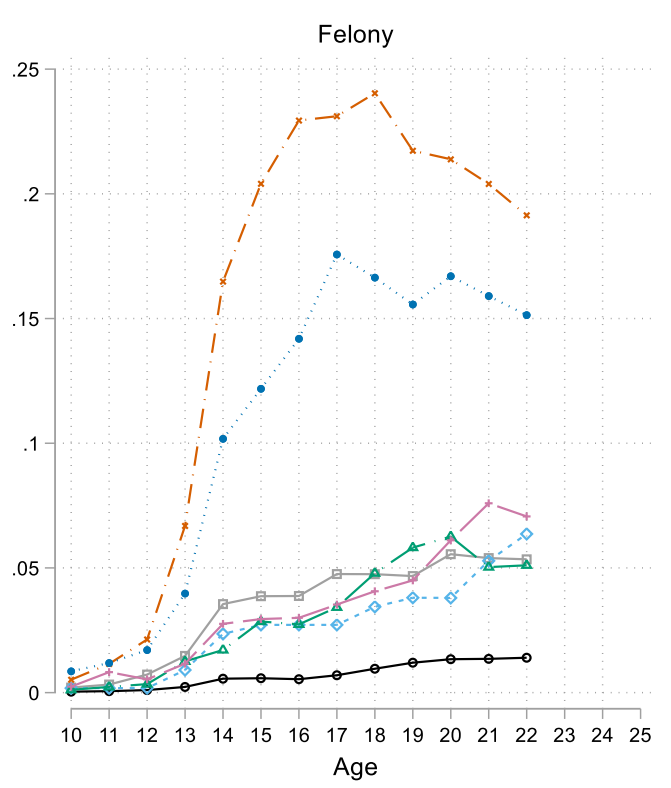

- No inititative $\quad \square-$ In-home initiatives

$\longrightarrow$ Enhanced foster homes $\quad$ *. MST

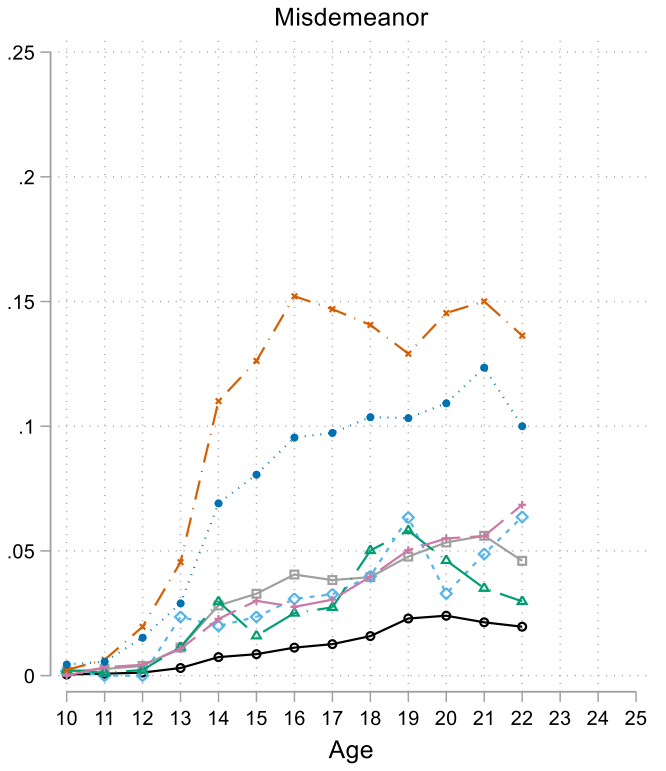

Kinsip foster homes

- Foster homes

Figure B1: Criminal charges by type of child welfare services initiative (birth cohorts 1992-1995). 

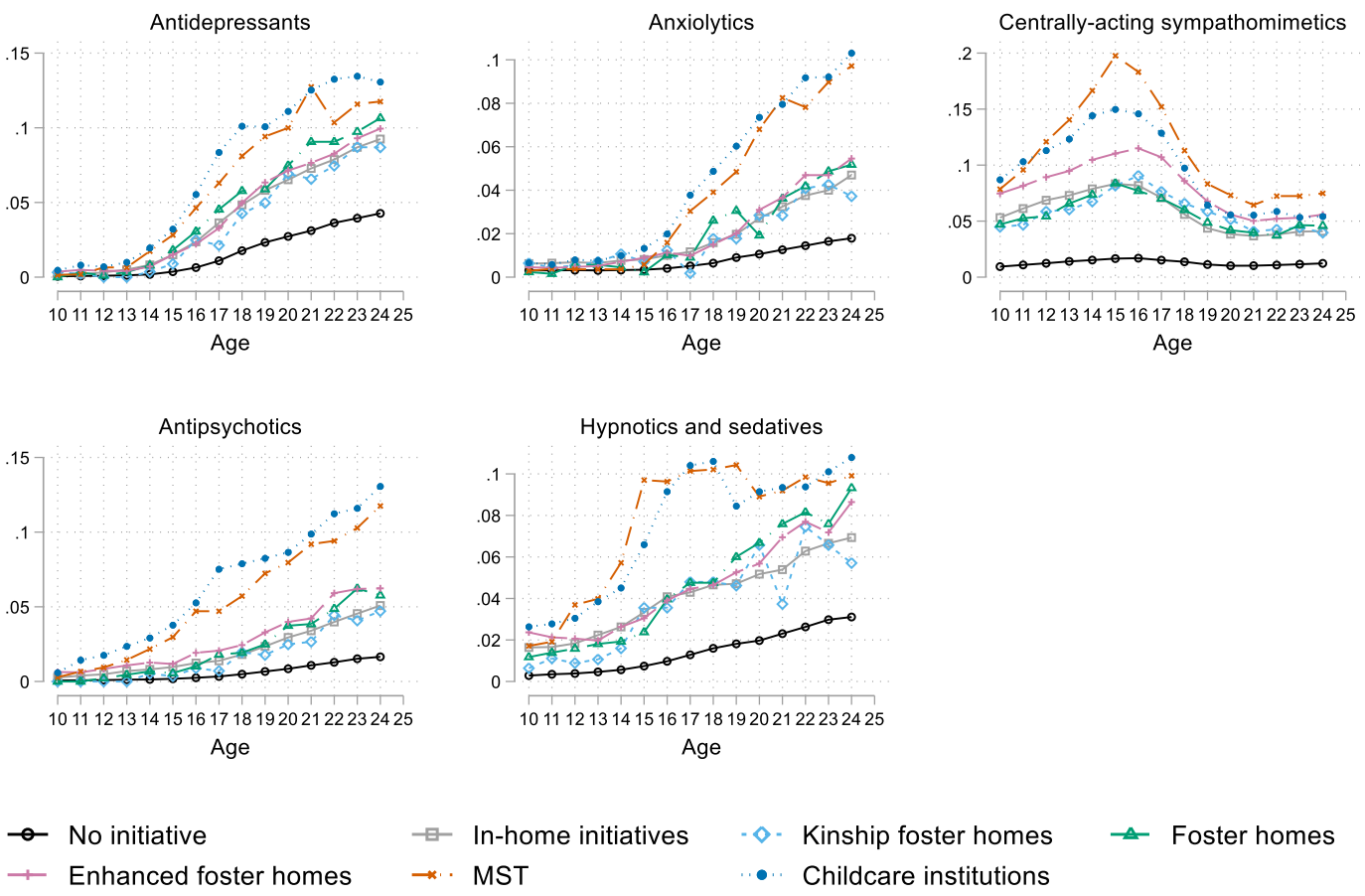

$$
\begin{aligned}
& \square-\text { In-home initiatives }-\diamond \cdot \text { Kinship foster homes } \\
& \text { *..MST }
\end{aligned}
$$

Figure B2: Prescription drugs by type of child welfare services initiative (birth cohorts 1992-1995).
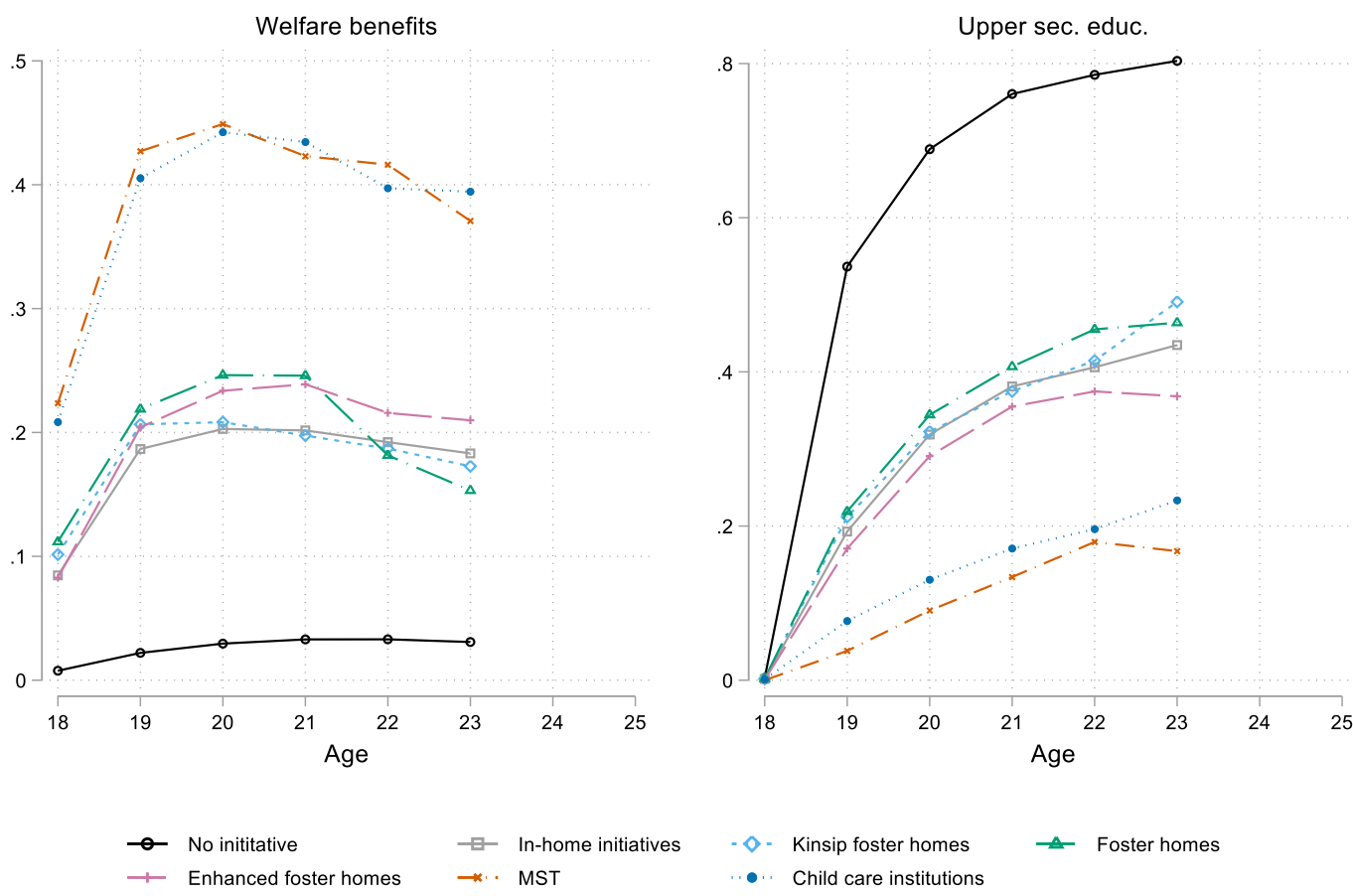

Figure B3: Welfare benefits and upper secondary education completion by type of child welfare services initiative (birth cohorts 1992-1995). 


\section{Online Appendix C: Life-course patterns by age at contact}

This online appendix supplements the main text by examining life-course patterns by children's timing of contact with child welfare services. We distinguish between three child welfare groups: those in early contact only (ages 0-5), persistent contact (sometime between ages 0 and 18), and late contact only (ages 14-18). The results are restricted to the birth cohorts 1992-1995, where we can observe nearly complete child welfare services histories. See Appendix Table A3 for more details about birth cohort coverage rates.
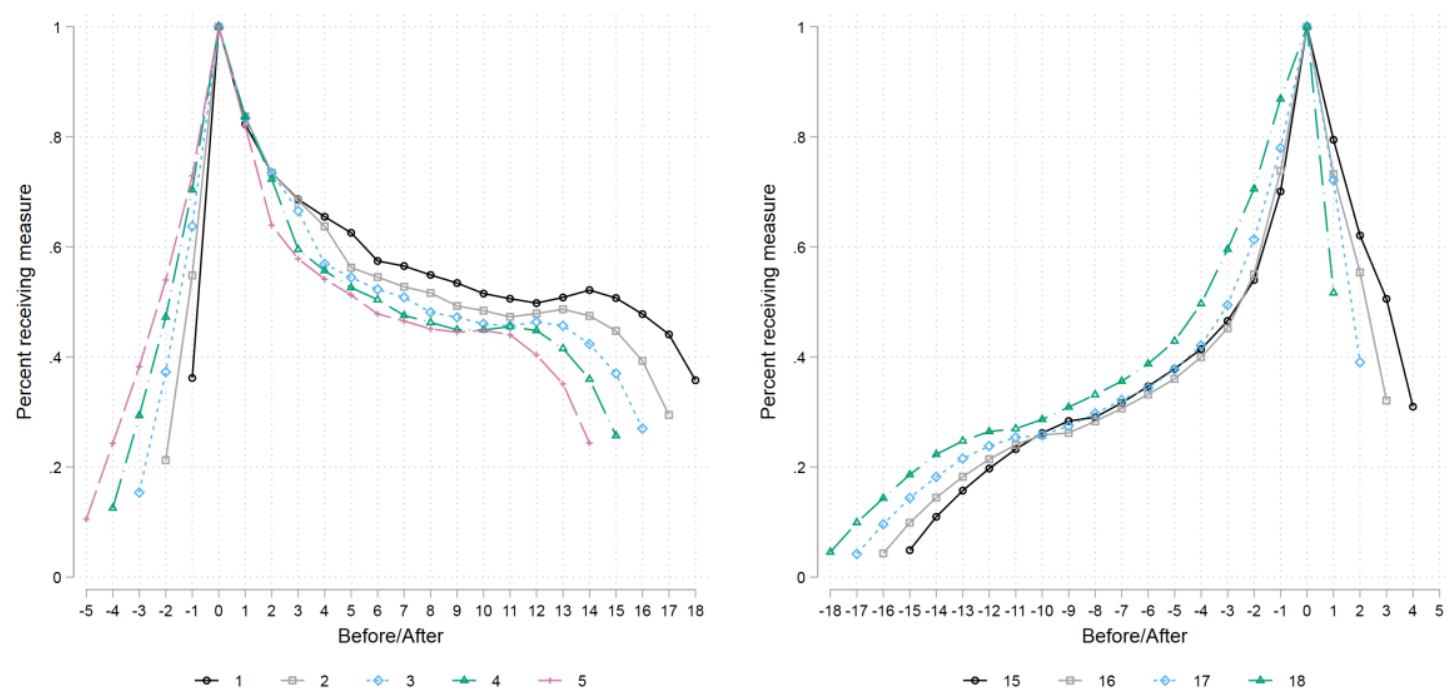

Figure C1: The persistence in the child welfare system by the age of child welfare contact. The results show the proportion of children who receive an initiative a given year who also receives initiatives the years before and after.

Note: Each line represents an age group, with ages 1 to 5 on the left-hand side and 15-18 on the righthand side. At zero, each line is 1 , which means that all receive an initiative. The values above (below) 0 show the proportion of children also receiving an initiative at the years after (before). Note that the number of children in various age groups varies.

Before looking at the characteristics and life-course trajectories, let us describe at which age children get in contact with child welfare services in Norway. Generally, there is a lot of fluidity within the child welfare services in Norway, with a large proportion of children going in and out of the child welfare services. Figure C1: shows the proportion of children who receive a child welfare services initiative in a given year that also receives some initiative the years before and after. For example, about $65 \%$ of the children in contact with the child welfare services at the age of 1 are still so at 5. 
Approximately half of the children in contact with child welfare services in early childhood are long-term clients. In contrast, only about a quarter of the children in contact with welfare services at the age of 15 had contact at 5 years of age.

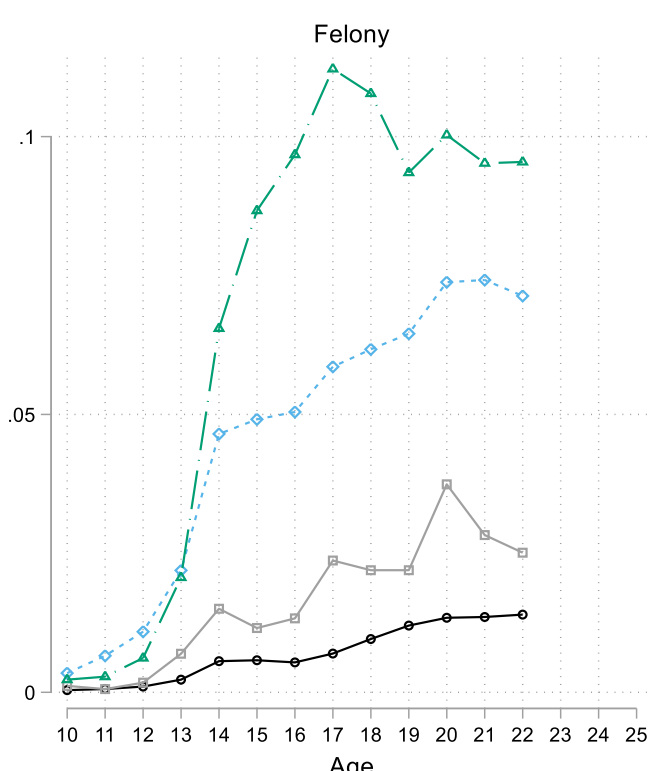

Age

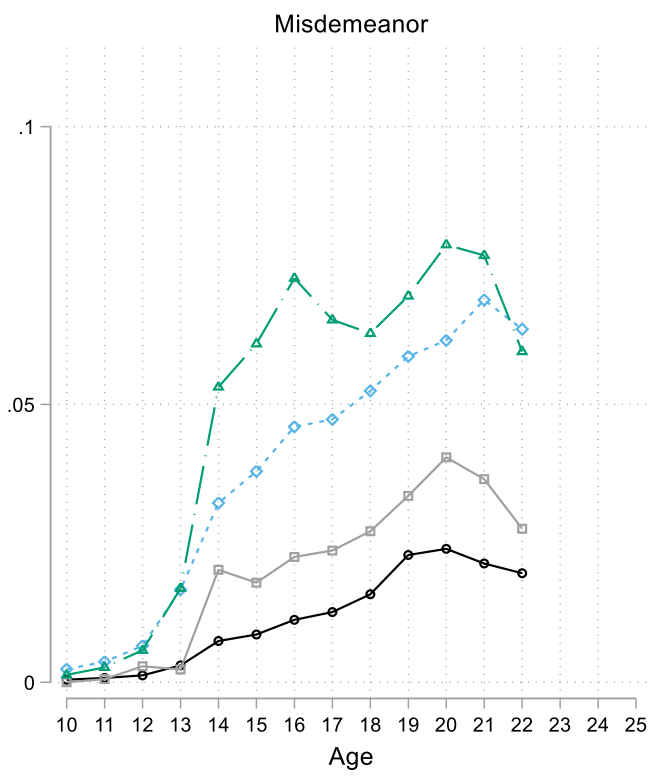

- Early (ages 0-5

$\triangle \quad$ Late (ages 14-18)

Figure C2: Criminal charge by timing at contact (birth cohorts 1992-1995). 

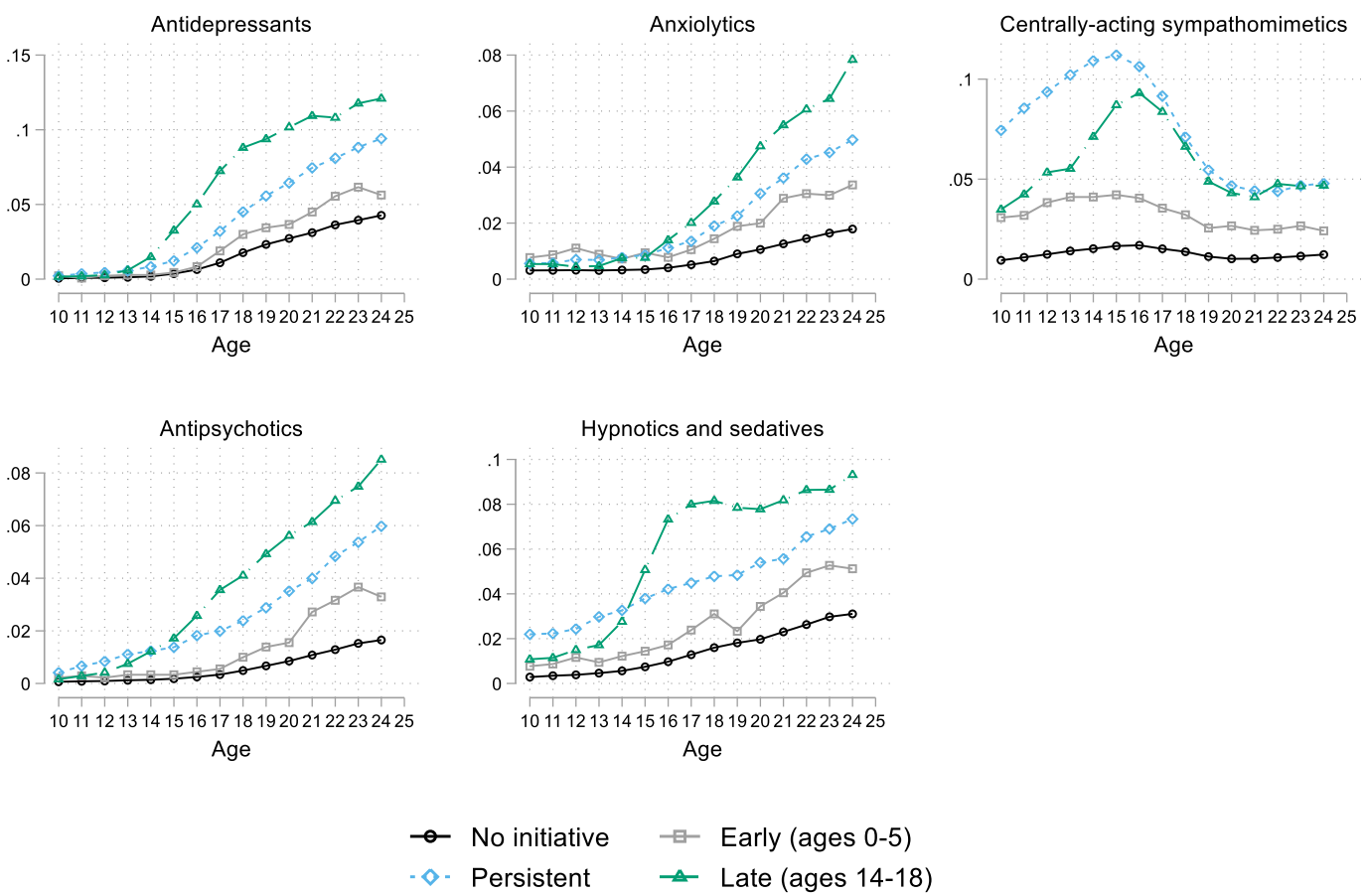

Figure C3: Prescription drugs by timing at contact (birth cohorts 1992-1995).
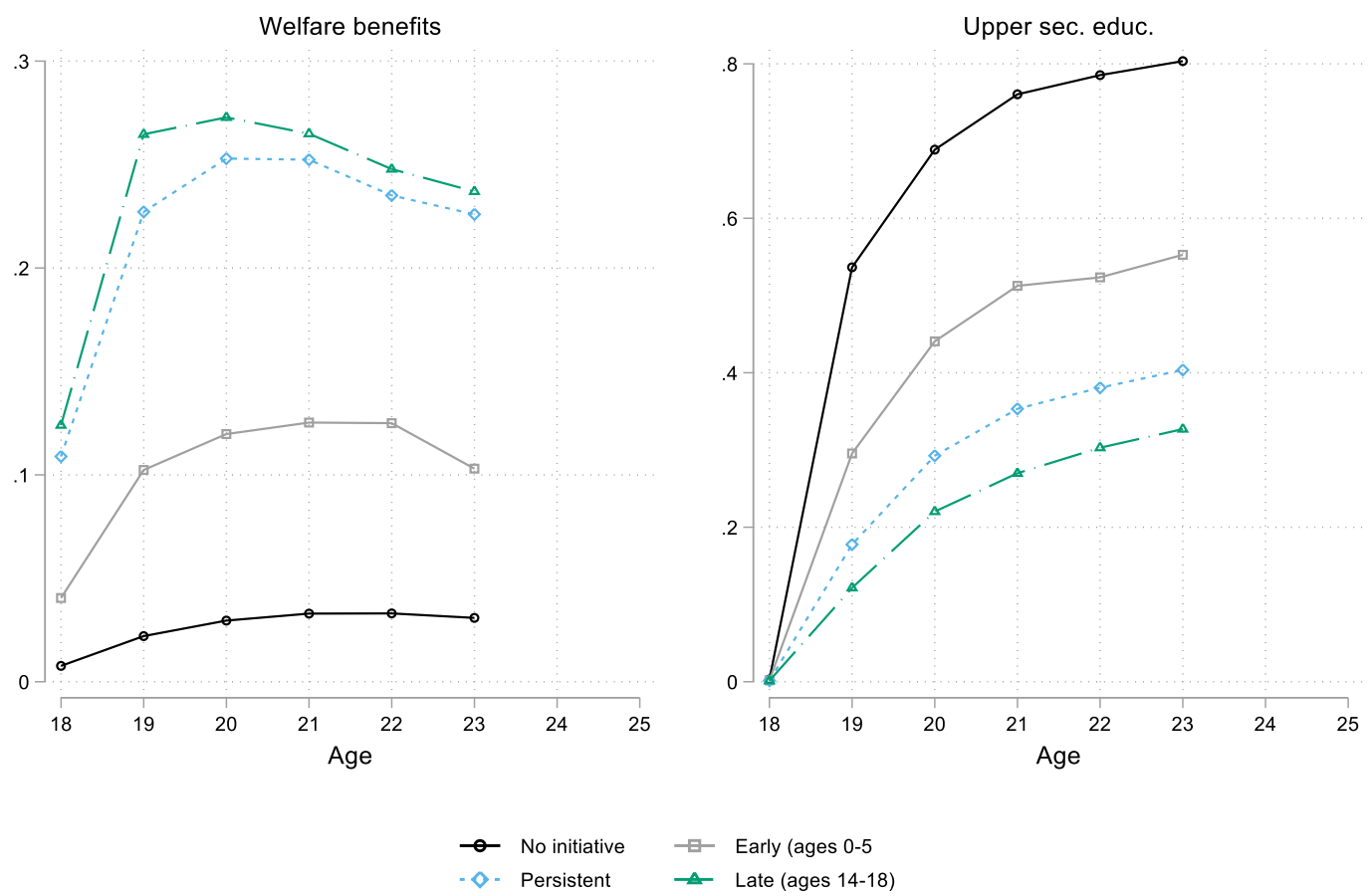

Figure C4: Welfare benefits and upper secondary education completion by timing at contact (birth cohorts 1992-1995). 